\title{
Efficacy of compost amendments and extracts in the control of foliar disease in organic tomato production
}

\author{
William Kraft Murray \\ West Virginia University
}

Follow this and additional works at: https://researchrepository.wvu.edu/etd

\section{Recommended Citation}

Murray, William Kraft, "Efficacy of compost amendments and extracts in the control of foliar disease in organic tomato production" (2005). Graduate Theses, Dissertations, and Problem Reports. 2220. https://researchrepository.wvu.edu/etd/2220

This Thesis is protected by copyright and/or related rights. It has been brought to you by the The Research Repository @ WVU with permission from the rights-holder(s). You are free to use this Thesis in any way that is permitted by the copyright and related rights legislation that applies to your use. For other uses you must obtain permission from the rights-holder(s) directly, unless additional rights are indicated by a Creative Commons license in the record and/ or on the work itself. This Thesis has been accepted for inclusion in WVU Graduate Theses, Dissertations, and Problem Reports collection by an authorized administrator of The Research Repository @ WVU. For more information, please contact researchrepository@mail.wvu.edu. 


\title{
EFFICACY OF COMPOST AMENDMENTS AND EXTRACTS IN THE CONTROL OF FOLIAR DISEASE IN ORGANIC TOMATO PRODUCTION
}

\author{
by \\ William Kraft Murray \\ Thesis submitted to the Davis College of Agriculture, Forestry and Consumer Sciences \\ at West Virginia University \\ in partial fulfillment of the requirements \\ for the degree of \\ Master of Science \\ in \\ Plant and Soil Science
}

Approved by

James Kotcon, Ph.D., Committee Chairperson

William Bryan, Ph.D.

Louis McDonald, Ph.D.

Alan Sexstone, Ph.D.

Environmental Microbiology/Plant Pathology

Morgantown, West Virginia

2005

Keywords: Alternaria solani, compost tea, early blight, Lycopersicon esculentum, tomato 


\begin{abstract}
EFFICACY OF COMPOST AMENDMENTS AND EXTRACTS IN THE CONTROL OF FOLIAR DISEASE IN ORGANIC TOMATO PRODUCTION

by William Kraft Murray

Effects of compost amendments and extracts on tomato foliar disease severity and yield were assessed in greenhouse and field experiments. Aerated and nonaerated compost tea extracts (CT) prepared from seven composts were applied to the leaves of two tomato cultivars in the greenhouse. Plants treated with CT from hay compost had less disease than the control in one greenhouse experiment. Mushroom CT increased disease severity in most experiments, and was significantly higher than the control in one experiment. The cultivar 'Brandywine' had a significantly higher disease severity ( $\mathrm{P}=0.0001)$ than ' $\mathrm{WV}$ ' 63 '.
\end{abstract}

Compost at 2.5, 5, 10, and 20 tons/acre significantly increased fruit yield compared to a control with no amendments. Disease severity was lower in the control and 10 and 20 tons/acre treatments than at 2.5 and 5 tons/acre.

In a second field experiment, yields were significantly lower $(\mathrm{P}=0.01)$ in plots amended with hardwood bark compost or blood meal than with dairy manure or yard waste compost. Early blight disease severity (AUDPC) varied significantly among compost treatments $(\mathrm{P}<0.05)$, but $\mathrm{CT}$ had no significant effect on fruit yield or early blight severity.

In a third field experiment, compost amendments had a significant effect on biomass $(\mathrm{P}=0.0012)$ and fruit yield $(\mathrm{P}=0.0001)$ but not on disease. Disease severity in $\mathrm{CT}$ treatments differed significantly $(\mathrm{P}=0.0493)$ but no single $\mathrm{CT}$ treatment differed from the control. 


\section{DEDICATION}

This work is dedicated to my parents, Hugh Patrick Murray (1926 to 2005) and Mary Kraft Murray. Both of them have inspired and encouraged my interest in agriculture and ecology. 


\section{ACKNOWLEDGMENTS}

This research was made possible by financial support from the West Virginia Agriculture and Forestry Experiment Station Hatch Project "WVA00447" and from the USDA SARE Project "LNE02-158." The Department of Plant Pathology at Cornell University generously provided a culture of the fungal pathogen investigated in this study

I first wish to acknowledge the spirit of trust and cooperation that prevails in the small department at Brooks Hall for plant pathology and environmental microbiology. In a world of increasing specialization, students, staff, and faculty have displayed a kind of support for one another and a sense of common purpose that is becoming all too rare.

I particularly thank my advisor, Dr. James Kotcon, who tirelessly supported my research and edited countless drafts of this document. His remarkable energy and enthusiasm have been a true inspiration. I also thank the other members of my committee, Dr. William Bryan, Dr. Louis McDonald, and Dr. Alan Sexstone for their timely and patient help on issues of plant health, soil fertility, and on matters microbiological.

Fellow graduate students have been a great source of support and solidarity both in the classroom and with research. Each and every one has helped me at some point to improve my dubious technical and computer skills. Field experiments would not have been possible without the efforts of the farm staff and many interns and undergraduate students. In particular I thank Kristy Altman, Paul Emerson, Adam Gray, Sarah Kotcon, Cassandra Nelson, Jason Nicholson, Tim Nickerson, Jessica Taylor, Norman Varnes, and David Wilson for their assistance with irrigation and in transplanting, mulching, staking, and harvesting research tomatoes over two growing seasons.

Finally, the West Virginia University greenhouse staff has been a fine model for fostering a conducive environment for education and research in the often frenzied academic world. My thanks go to Sue Myers, Gail Sikorsky, and Carol McCarthy for their steady and patient support of my greenhouse research. I also thank and acknowledge all others, too numerous to name, who have helped me over five semesters. Any errors, omissions, or other shortcomings in this work are my own. 


\section{TABLE OF CONTENTS}

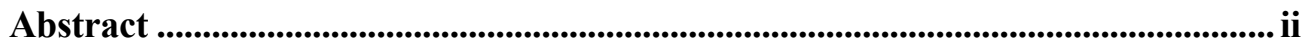

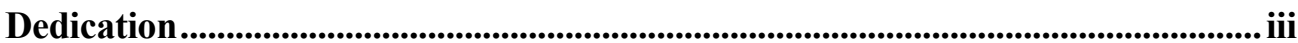

Acknowledgments............................................................................................................. iv



List of Figures ......................................................................................................... vi





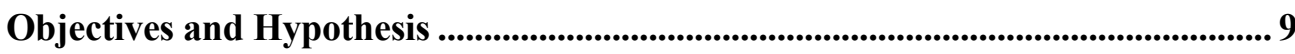

Chapter 1: Effect of compost amendment rates on early blight incidence in organic tomato production

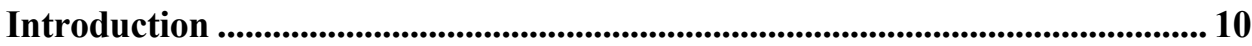

Materials and Methods ......................................................................................... 10

Results ..................................................................................................................................................... 12

Discussion ........................................................................................................................................ 20

Chapter 2: Efficacy of compost extracts in the control of early blight in potted greenhouse tomato plants



Materials and Methods ....................................................................................................... 24

Results ......................................................................................................................................................... 26

Discussion ................................................................................................................................................. 35

Chapter 3: Effect of solid compost, compost extracts, and their interactions on the incidence of foliar disease in organic tomato production

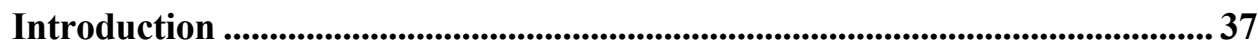

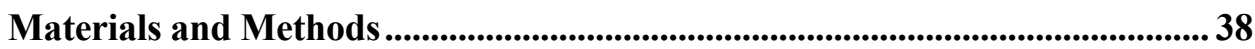

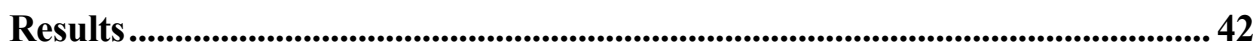

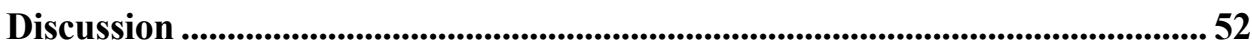

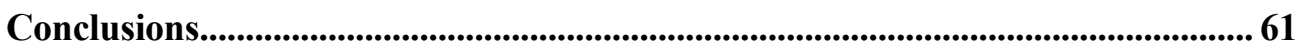

Appendix................................................................................................................................. 62

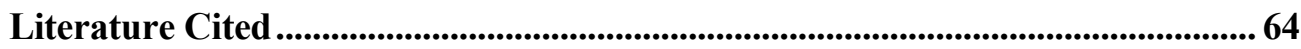




\section{LIST OF FIGURES}

$\underline{\text { Page }}$

Figure 1.1. Mean (and standard error) of total and marketable fruit yield at five compost rates 13

Figure 1.2. Mean number (and standard error) of total and marketable fruit per plot at five compost rates. 14

Figure 1.3. Mean tomato dry shoot biomass (and standard error) at five compost rates . 15

Figure 1.4. Mean tomato dry root biomass (and standard error) at five compost rates. 16

Figure 1.5. Cumulative disease severity over time expressed as Area Under the Disease

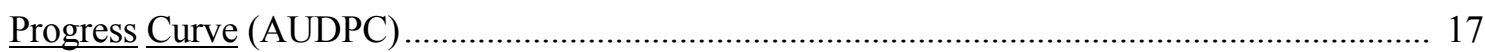

Figure 1.6. Percent total disease in tomato plants by treatment over ten weeks ...................... 18

Figure 1.7. Mean percent green leaf area remaining (GLAR) on tomato plants...................... 19

Figure 2.1. Percent disease severity on individual ' $\mathrm{WV}$ ' 63 ' tomato leaves treated with nonaerated compost tea (NCT) in Experiment 1

Figure 2.2. Percent disease severity on individual 'Brandywine' tomato leaves treated with nonaerated compost tea (NCT) in Experiment 2.

Figure 2.3. Percent disease severity on individual 'WV ' 63 ' tomato leaves treated with nonaerated compost tea (NCT) in Experiment 3

Figure 2.4. Percent disease severity on individual 'Brandywine' tomato leaves treated with aerated compost tea (ACT) 4 days after inoculation in Experiment 5

Figure 2.5. Percent disease severity on individual 'Brandywine' tomato leaves treated with aerated compost tea (ACT) 8 days after inoculation in Experiment 5

Figure 2.6. Percent disease severity on individual ' $\mathrm{WV}$ ' 63 ' tomato leaves treated with aerated compost tea (ACT) 4 days after inoculation in Experiment 6. 33

Figure 2.7. Percent disease severity on individual ' $\mathrm{WV}$ ' 63 ' tomato leaves treated with aerated compost tea (ACT) 8 days after inoculation in Experiment 6

Figure 3.1. Mean dry weight in grams of tomato shoots from plots with 10 soil amendments, with or without the corresponding compost tea (CT)

Figure 3.2. Mean fresh fruit weight in kilograms from plots with 10 soil amendments, with or without the corresponding compost tea (CT)

Figure 3.3. Mean number of fruit from plots with 10 soil amendments, with or without the corresponding compost tea (CT) 
Figure 3.4. Mean dry weight in grams of tomato shoots from plots receiving dairy manure compost (DM), yard waste compost (YW), or blood meal soil amendments and sprayed with aerated (ACT) or nonaerated (NCT) compost tea .................................................. 47

Figure 3.5. Mean fresh weight in kilograms of fruit from plots receiving dairy manure compost (DM), yard waste compost (YW), or blood meal soil amendments and sprayed with aerated (ACT) or nonaerated (NCT) compost tea ................................................................. 48

Figure 3.6. Mean number of fruit from plots receiving dairy manure compost (DM), yard waste compost (YW), or blood meal soil amendments and sprayed with aerated (ACT) or nonaerated (NCT) compost tea.

Figure 3.7. Early blight disease severity in compost and compost tea treatments

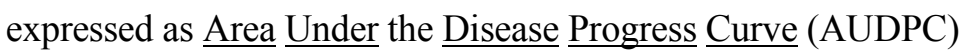

Figure 3.8. Foliar disease severity in compost and compost tea treatments expressed as

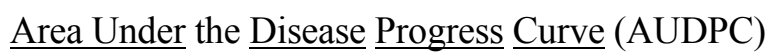




\section{LIST OF TABLES}

$\underline{\text { Page }}$

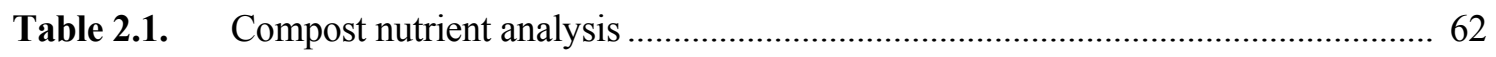

Table 3.1. Effects of soil treatment on fruit weight and shoot biomass .................................. 40

Table 3.2. Mean dry shoot biomass, fruit weight, and green leaf area remaining



Table 3.3. Effects of compost extracts on Area Under the Disease Progress Curve

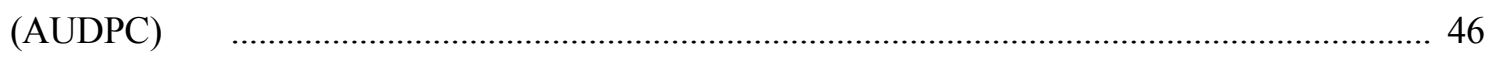

Table 3.4. Effects of compost amendments and extracts on yield and disease ...................... 53

Table 3.5. Effects of compost amendments on yield and disease in three experiments .......... 56

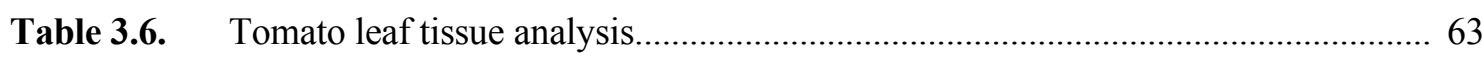

Table 3.7. Effect of compost soil amendments on yield and disease in three experiments.... 59 


\section{Literature Review}

Humans produce food and fiber in agroecosystems. These systems are simpler than natural ecosystems to the extent that they are managed for human ends. Simplicity, however, is relative. A great many complex ecological interactions at many levels are at play in even the most tightly managed agricultural system we can devise. Problems in agriculture with disease, weeds, and pests signify the limits to human control of the countless variables that we attempt to manage.

Disease management is a central problem in agriculture and the focus of this research. Disease prevention through crop breeding is the traditional approach to disease control. Conventional agriculture couples this with pesticides, particularly fungicides, the use of which has soared in the past 50 years. This use has contributed to dramatic gains in agricultural productivity. However, the environmental and public health costs of increased chemical use are also high, though often difficult to quantify. Input costs for conventional agriculture continue to rise and diminishing marginal returns are becoming evident for pesticides as well as other system inputs (Gliessman, 1998).

The thrust of modern agricultural practice and research is to further simplify and more tightly regulate crop production. An alternative agricultural paradigm is to deliberately model agroecosystems on natural ecosystems (Fukoka, 1978 and Jackson, 1980). The "design with nature" approach is an effort in applied ecology. Organic agriculture, a system that places particular emphasis on long-term soil health (Rodale, 1973), fits broadly within this paradigm. It is a lowinput approach that is knowledge, rather than capital, intensive yet receives comparatively little attention or research funding.

Disease management is a major problem for organic growers whose disease control options rely heavily on prevention through sanitation, crop rotation, and the use of resistant cultivars. When disease problems occur, organic certification rules (USDA, 2002) permit the use of copper compounds for bacterial and fungal disease, but this leads to long-term copper accumulation in soils with adverse effects on earthworms and nitrogen-fixing microbes (Diver et al., 1999) and can result in copper-resistant pathogen strains (Sahin and Miller, 1996). The well-known biocontrol agent Trichoderma harzianum has been used fairly successfully against a number of plant pathogens and 
is formulated as an in-furrow soil treatment granule, but this practice is not widespread (Harman, 2000). Achieving consistent disease suppression by biological means remains a challenge in organic agriculture. It is an area that merits more scientific research.

\section{Compost for Disease Control}

Compost is the product of biological reduction of organic waste to humus. It has been used for centuries as a soil amendment to improve both the fertility and structure of agricultural soils (Rodale, 1973). Organic growers since the 1920s have contended that the use of compost also reduces plant disease levels. This assertion is controversial and not well documented. On the one hand, the literature on disease suppression is substantial: the USDA Microbial Lab in 1998 compiled a bibliography with 167 references on the topic (Ringer, 1998). Yet critics are quick to note that the literature includes more articles from the popular press than from peer-reviewed scientific journals.

Research investigates compost treatments by assessing response at the plant level or examines changes induced at the soil microbial level. The focus in both approaches has been mainly on root disease with considerable research attention and practical success in the greenhouse and nursery industry. More research is needed on foliar disease and on field crops.

Application of water extracts of compost to plants is a fairly recent development. References in the organic literature to water extracts date back to 1924 (Brinton et al., 1996). The earliest article on compost extracts in a peer-reviewed journal examines the effects on nematodes (Hunt, et al., 1973). Foliar disease receives more emphasis in trials with compost extracts. A recent literature review by Scheuerell and Mahaffee (2002) shows that few if any studies test compost soil amendments and extracts in a single experiment.

This research combines the two approaches in field experiments over two seasons. It examines the

effects of compost amendments, extracts, and their interactions on the incidence of early blight, the most important foliar disease of tomatoes in the eastern United States.

\section{Compost as a Soil Amendment}

Biological management of soil organic matter with compost and other amendments is an approved and traditional disease management practice for organic producers. Compost for disease reduction 
is a form of biological control. In a general sense, biological control of disease is that "mediated by an additional organism(s), which changes the outcome of the interaction between the environment, a pathogen, and the plant host" (Maloy and Murray, 2001). However, given the complexity of compost, it may be more accurate to emphasize a community effect rather than mediation by a single organism or a small group of organisms. The addition of compost amendments leads to numerous shifts and changes in the soil microbial community which can result in a disease suppressive or conducive environment. Disease suppression can be seen broadly as a function of soil ecosystem health (Van Bruggen and Semenov, 2000). Describing and measuring indicators of soil health is a challenge; with compost in particular, soil health is clearly associated with specific stages of microbial succession depending on the pathogen in question.

Biological control shows potential, but is not as widely used as application of chemicals for disease control. Many more chemical than biological agents have been documented as effective against any given disease (Pharand et al., 2002). The efficacy of chemical agents is also more consistent. Quality control criteria are more difficult to develop for biological agents in general and for compost in particular. Biological control with compost is best viewed in a broader integrated pest management (IPM) context. It offers no quick, easy, or universal solutions, but demands instead our best agroecological understanding of specific disease problems.

The anecdotal literature in the popular press tends to overgeneralize about compost (Chalker-Scott, 2001). Composts vary widely as a function of both the feedstocks from which they are made and the composting process employed. Variability is very large between different composts. It may also be considerable within different batches from the same feedstock. A related criticism is that a particular compost is often not sufficiently characterized or analyzed in terms of its chemical and physical properties or its microbial community. This may partly explain the often inconsistent results which abound in the literature on compost for disease control.

A notable exception is the greenhouse and nursery industry where fairly consistent and costeffective suppression of Pythium, Phytophthora, and Rhizoctonia diseases with potting media has been extensively documented (Hoitink et al., 1997). Root rot diseases associated with these fungal pathogens were prevalent in the 1960s. The industry responded in the 1970s with compost barkamended container mixes which partially replaced sphagnum peat in potting media for greenhouse and nursery plants. This has greatly reduced the need for chemical fungicides in these industries. 
Specific chemical, physical, and biological properties in potting media are required for consistent disease suppression. Peat as a container medium has useful physical properties. However, as a highly humified material it is disease conducive to root pathogens when used as the sole organic component in a potting mix and does not support the activities of biocontrol agents. Immature composts are not only less suppressive, but can actually favor pathogen (Boehm et al., 1993).

Results with compost for disease suppression vary according to compost type, maturity, and composting method. Composted hardwood bark (CHB) in particular appears to be disease suppressive to major soilborne pathogens and has been studied in considerable detail (Nelson and Hoitink, 1981). Damping-off decreased in direct proportion to the substitution of peat with composted hardwood bark with suppression believed to result from competitive inhibition (Stephens et al., 1981). Gliocladium virens and Trichoderma spp. are the fungi that occur in large numbers in $\mathrm{CHB}$ and are associated with its suppressiveness to damping-off caused by Rhizoctonia. The two most effective bacterial species are Flavobacterium balustinum and Xanthomonas maltophilia. These bacterial and fungal antagonists are the taxa most easily isolated and which rapidly colonize organic matter. They work more effectively in combination than individually, suggesting a community effect of which only a few members have so far been identified (Hoitink and Fahy, 1986). Chemical inhibitors that reduce the production of sporangia and zoospores in Phytophthora spp. have also been identified in oak bark (Hoitink et al., 1977) and in spent mushroom compost (Cronin et al., 1996).

The body of research from the greenhouse and nursery industries with its focus on root disease can and should lead the way for general biological control of plant pathogens, but the findings do not transfer readily to crops at the field level where variables are much more difficult to control. There is considerably less documentation for disease control with compost in field crops. Negative reports on disease suppression are probably underreported but include failure of compost amendments to reduce Phytophthora stem rot of greenhouse peppers (Kim et al., 1997), lack of suppression in Phytophthora fruit rot in pumpkins (McGrath, 1996), and no effect in the suppression of dampingoff by Rhizoctonia solani in greenhouse bean seedlings (Voland and Epstein, 1994). Other research, however, indicates that ten of fifteen composts prepared from varied feedstocks significantly reduced damping-off of creeping bentgrass compared to a sand control (Craft and Nelson, 1996). In a similar study, all but one of five composts were as effective as a fungicide control treatment in suppressing dollar spot of turfgrass caused by Sclerotinia homeocarpa (Boulter et al., 2002). 
Composts with high populations of heterotrophic fungi and antibiotic-producing actinomycetes were most suppressive to Pythium damping-off in the 1996 creeping bentgrass study. The loss or reduction of suppressiveness by heat or radiation treatment strongly suggests that the effect is biological and indicates antibiosis as the probable disease suppression mechanism (Fravel, 1988). Addition of small amounts of nonautoclaved compost to the autoclaved material restored suppressiveness (Craft and Nelson, 1996). Research on cucumber and Arabidopsis (Zhang et al., 1998) and apple (Cronin et al., 1996) used autoclaving and radiation, respectively, to similarly indicate antibiosis as a probable mechanism. Disease suppression has also been correlated with compost pile temperature zones. Compost samples from the center of the pile were more conducive to Pythium damping-off than edge samples of lower temperature (Chen et al., 1987 and Kuter et al., 1988), indicating that the stage of microbial succession is critical in disease suppression.

A suppressive compost antagonistic to a specific pathogen might reduce the number of infective propagules in the soil environment by a mechanism such as predation or parasitism. This would reduce potential infection through rainsplash events, and thus reduce disease incidence on foliage. More often, however, the effect is less direct and not well documented for foliar diseases (Weltzien, 1991). One less direct mechanism may be the presence of plant growth-promoting rhizobacteria (PGPR) in the suppressive compost. The effects of PGPR are more systemic in nature, benefiting plants in several ways. These include the production of secondary metabolites and siderophores by plants and antagonism to root pathogens in the rhizosphere. They also promote soil fertility through dinitrogen fixation and phosphate solubilization (Goldstein, 1986 and De Brito Alvarez et al., 1995). Siderophores are extracellular, low-molecular-weight compounds which efficiently sequester iron in the plant root zone, making it unavailable to some soil pathogens. The ability to sequester iron can confer a competitive advantage on microorganisms beneficial to plant growth (Leong, 1986).

De Brito Alvarez et al. (1995) examined the effects of four manure-based composts and a soil/perlite control on the PGPR microbial community in the rhizosphere of tomato plants. They noted significant correlations between types of compost amendments and microbial community composition, and confirmed that compost does not stimulate net microbial growth but does change species composition. The rhizobacteria of compost were superior or equal to those of the soil/perlite 
control in terms of pathogen antagonism. Compost increased the population of siderophore producers, creating conducive conditions for the proliferation of soil root pathogen antagonists.

Induction of systemic resistance is another possible explanation of disease suppression by compost soil amendments. The growing literature on induced resistance for disease control points to many biological and nonbiological elicitors for plant defense responses. Induced systemic resistance (ISR) and systemic acquired resistance (SAR) are the two most clearly characterized forms of induced resistance (Vallad and Goodman, 2004). ISR is initiated by PGPR, including Pseudomonas and Bacillus species, commonly found in compost. Three Bacillus species reduced foliar disease symptoms caused by the tomato mottle virus in tomato field trials in which the PGPR strains were applied as powder amendments to the planting medium (Murphy et al., 2000 and Zehnder et al., 2001). SAR is a mechanism by which a plant's defense response to one pathogen or other stimulus leads to enhanced resistance against another pathogen. SAR can be triggered by PGPR, pathogens, and phytotoxic chemicals such as salicylic acid (Wei et al., 1996 and De Meyer and Hoefte, 1997). Microorganisms known to induce SAR have been identified and described and some of them are present in disease suppressive compost. A certain population threshold must be reached for SAR to be effective.

\section{Compost and Tomato Production}

Inconsistent results were evident in a field study on organic and conventional tomato production (Abbasi et al., 2002). A high rate of cannery waste compost amendments reduced the incidence of anthracnose compared to control treatment and low compost rate treatments in one of two years when disease pressure was high. There was no significant treatment effect in the year of low disease pressure. Under conventional production at a different site, composted yard waste treatments at low and high rates increased foliar disease when compared to the non-compost control. However, the effect was opposite for bacterial spot on fruit, with higher disease incidence in the control than in the compost treatments. The conventional study also measured the effects of greenhouse planting mix on field disease incidence. Standard potting mix resulted in higher bacterial spot incidence but lower anthracnose incidence in field plants in one of two years than composted pine bark-amended potting mix inoculated with the biocontrol agents Trichoderma hamatum 382 and Chryseobacterium gleum 299. 
Another study on tomato showed significant reduction in southern blight caused by the soilborne fungus Sclerotinia rolfsii over two seasons by compost amendments compared to synthetic fertilizer (Bulluck and Ristaino, 2002). Three organic soil amendments, compost from cotton gin trash (CGT), swine manure, and rye-vetch as green manure, were compared with a conventional 10-1010 fertilizer for effects on propagule densities of bacteria and fungi antagonistic to $S$. rolfsii in the soil microbial community. All three organic amendments significantly reduced disease incidence in tomatoes in both study years in comparison with the synthetic fertilizer; the largest reduction was with the CGT compost. Microbial analysis indicated that soil treated with swine manure and CGT composts had higher densities of culturable bacteria than the other two compost treatments. Data from the study indicated that germination of sclerotia was reduced by the organic amendment treatments, yet the researchers stop short of naming an actual mechanism by which this apparent biological control of disease occurs. This is characteristic of the literature on disease suppression with compost. Still, the suppressive effect on the disease was great enough that the researchers argue CGT compost "...could be used as an alternative to or in combination with conventional soil fumigation or fungicides for disease control in problem areas of fields." This study makes a limited claim about the efficacy of a single type of compost on a specific disease over two growing seasons on a particular site. The CGT compost example underscores the complexity of this disease control approach and the limited applicability of any single success to other crops or pathogens. Disease suppression efficacy that does occur is probably specific by crop, pathogen, site, and compost.

\section{Compost Tea}

In the past twenty years, water extracts of compost have been applied as foliar sprays, seed dips, and soil drenches for fertility benefits and disease control. Various terms have been applied to these extracts: compost tea, organic tea, compost extract, amended extract, steepage, slurry, and watery fermented compost extract. "Compost tea" (CT) is the most common designation used by researchers and practitioners for extracts prepared in numerous ways (Scheuerell and Mahaffee, 2002). Anecdotal evidence supporting claims of disease suppression with CT abounds, but controlled, replicable experiments are scarce and results are inconsistent at best.

CT experimentation has grown very rapidly in the past ten years. In simplest terms, CT is the combination of compost with water for a specified period of time to yield a liquid for agronomic use. Research on the effects of CT on leaf surface (phyllosphere) microflora dates to a 1986 study which reported reduction in the incidence of powdery mildew on grapevine leaves by CT (Weltzien 
and Ketterer, 1986). The same researchers later reported similar success with control of late blight in tomatoes and potatoes (Weltzien, 1991). While foliar feeding is a possible benefit of CT, the past decade has seen a surge of interest in its potential for disease control (Diver, 1998). Early CT research emphasized nonaerated brewing of relatively long duration; the more recent trend is on faster brewing under aerated conditions (Ingham, 2002). Few studies have directly compared the efficacy of nonaerated with aerated CT. One field experiment makes this direct comparison. Aerated and nonaerated compost teas from composted dairy manure and composted yard waste were applied to tomato plants to test the effects on early blight of tomato.

\section{Early Blight and Septoria Leaf Spot of Tomato}

Alternaria solani is the fungal pathogen that causes early blight and is the name found throughout the literature and in this study. Recent research indicates that $A$. solani causes early blight on potato and a new species, A. tomatophila Simmons causes the disease on tomato (Simmons, 2000). The disease was first described in 1892 and occurs wherever tomatoes are grown. Sustained periods of leaf wetness are required for disease development, but a critical number of hours of high $(>80 \%)$ relative humidity is more important than daily mean relative humidity (Moore, 1942; Waggoner and Horsfall, 1969). The fungus overwinters on infected plant debris in the soil and on seed. Conidia germinate within two hours and directly penetrate the leaf through the cuticle or wounds. Lesions become visible under favorable conditions two or three days following infection. Sporulation occurs when lesions reach about $3 \mathrm{~mm}$ in diameter. Disease symptoms can affect stem, foliage, and fruit of the tomato and other solanaceous plants. The first symptoms are small, dark lesions that appear on older leaves. Concentric rings become visible as lesions expand. Stem lesions have pronounced concentric rings and fruit can be infected at the green or ripe stage.

Septoria leaf spot caused by the fungal pathogen Septoria lycopersici is another important foliar disease of tomato. Lesions resemble those of early blight, but fruit infections are rare. Symptoms appear first on oldest leaves and disease development moves upward towards younger growth. (Jones et al., 1997).

Compost, applied either as a soil amendment or as a water extract, has agronomic potential for disease control. Research is at a very early stage. The complexity and variability of compost suggest that focus on a single crop is most effective. This research examines the effects of compost 
amendments, extracts, and their interactions on foliar disease levels in organic tomato production. Experiments were conducted over two growing seasons in the greenhouse and field.

\section{Objectives}

1. Determine the optimal rate of compost soil amendment for tomato fruit yield and foliar disease suppression.

2. Determine the effect of foliar application of compost extract on foliar disease incidence and fruit yield.

3. Compare feedstocks for compost soil amendments in order to reduce disease incidence or increase fruit yield.

4. Evaluate the interaction of compost and compost extracts on disease control and fruit yield.

\section{Hypotheses Tested}

1. Early blight disease incidence and tomato yield differ in plots amended with different rates of compost.

2. Extracts from different composts differ in their effects on early blight disease incidence and tomato yield.

3. Early blight disease incidence and tomato yield differ in plots amended with composts from different feedstocks.

4. There is a significant interactive effect of compost as a soil amendment with compost extract applied to foliage on disease level or yield. 


\section{CHAPTER 1: EFFECT OF COMPOST AMENDMENT RATE ON EARL Y B L IGHT INCI D E N C E IN OR G A N C TOMATO PRODUCTION}

\section{Introduction}

Composts from different feedstocks have been compared for their effects on tomato disease (Bulluck and Ristaino, 2002 and Abbasi et al., 2002) and on turfgrass disease (Craft and Nelson, 1996 and Boulter et al., 2002). Another research approach compares yield and disease severity between compost and no compost treatments (McGovern and Obreza, 1993 and MacNab and Beyer, 1996). The effect of variable nitrogen rates with chemical fertilizer on early blight severity has been examined (Zitter and Wolfe, 1989) but analogous field research based on different compost rates is lacking. Organic growers do not have clear compost rate recommendations. It is well established that compost amendments improve soil fertility and structure, but the idea that more is always better has not been proven. The relationship between crop yield and disease is complex and not fully understood in conventional or organic agriculture. A challenge in organic production is to find the compost rate that optimizes disease suppression and yield for a particular crop. In this experiment, tomatoes were grown in field plots with five rates of a single type of compost to compare the effects on disease and yield.

\section{Materials and Methods}

Seeds of the tomato cultivar 'WV '63' were started April 4, 2004 in a peat/composted dairy manure/perlite potting medium and grown in a greenhouse with no chemical fertilizer or pesticide treatment. Fifteen completely randomized research plots at the West Virginia University Organic Research Farm in Morgantown, WV had been amended annually for the previous 4 years with dairy manure compost at $0,2.5,5,10$, and 20 tons dry weight per acre with 3 replicates per treatment. These plots with Dormont silt loam soil received no other fertilizer or amendments in the past 4 years and were in cut flower production. Following the application of compost to plots, eight-weekold tomato plants were transplanted to the field on June 5, four plants per 1.2 by 1.8 meter plot with $0.6 \mathrm{~m}$ between plants and $0.8 \mathrm{~m}$ between rows. Four plants constituted an experimental unit. Each plant was individually staked and tied one week following transplanting. Plots were not mulched but were weeded three times during the growing season. Temperatures were below average in June, 
July, and August $\left[68.6^{\circ}\left(\right.\right.$ mean $\left.=69.4^{\circ}\right), 72.4^{\circ}\left(73.5^{\circ}\right), 69.7^{\circ}\left(72.1^{\circ}\right)$ F., respectively] and above average in September [66.7 $\left(65.9^{\circ}\right)$ F.] Rainfall was below average in July [3.58 (4.24)] and above average in June, August and September [4.26 (4.04), 5.5 (3.96), and 4.83 (3.35) inches, respectively]. Plants were watered once in mid-July with approximately 4 liters of water per plant.

Plants were inoculated with a spore suspension of Alternaria solani (isolate provided by Department of Plant Pathology at Cornell University). The fungal pathogen was cultured on V8 agar and divided every 10 days to ensure a steady supply of sporulating material. Two-week-old fungal colony surfaces were washed with distilled water and gentle brushing action to collect spores. Spore concentration was measured with a hemocytometer and the water volume adjusted to standardize the concentration at 20,000 spores $\mathrm{ml}^{-1}$ for spray inoculation. Plants were inoculated July 23 and then weekly from August 6 to September 3. The spore suspension was applied by spray bottle to lower leaves late evenings or early mornings during sustained leaf wetness periods that favored fungal spore germination.

Disease severity was monitored weekly from July 22 to September 23. All necrotic leaf area was estimated visually as a percentage of total leaf area in each plot. As general leaf senescence began by the middle of September, a second independent weekly estimate of percent green leaf area remaining (GLAR) for each plot was made September 17 and 24 and October 1 and 8. The final GLAR estimate was done just prior to harvest of shoot biomass.

Ripe and nearly ripe fruit were harvested weekly from August 11 to October 6. All remaining fruit were harvested on the final date. Fruit were counted and the total weight per plot recorded. Nonmarketable fruit (having cracks, holes, rot, or other blemishes) were separated from the total harvest. Total yield and marketable yield were recorded by plot. Plant stems were cut flush at the soil surface on October 8. The four plants from each plot were combined, oven-dried at $43^{\circ} \mathrm{C}$. for 9 days, and the shoot biomass weighed and recorded.

Four soil cores of $2.5 \mathrm{~cm}$ diameter and $15 \mathrm{~cm}$ depth were taken approximately $15 \mathrm{~cm}$ from the base of each plant on September 16. The four cores were combined, refrigerated, and washed 4 days later to estimate total root length using the line intercept method (Newman, 1966). Whole root systems of the four plants per plot were harvested October 14, washed to remove soil, and oven-dried at $43^{\circ}$ C. for five days to determine total dry biomass. 


\section{Statistical Analysis}

Data were analyzed with a one-way ANOVA. Tukey's HSD $(\mathrm{P}<0.05)$ was used to compare treatment means where significant F-values were found. Area under the disease progress curve (AUDPC) was calculated by summing over the season the products of the number of days between disease severity ratings times the rating on that date.

\section{Results}

Rate of compost amendment had a significant effect $(\mathrm{P}=0.0003)$ on fruit yield (Figure 1.1). Compost rates of 10 and 20 tons/acre produced significantly greater $(\mathrm{P}<0.05)$ fruit weight than the control. Yield increased as the rate of compost increased for both total and marketable weight. Total number of fruit and marketable number of fruit $(\mathrm{P}=0.0002)$ also increased as the compost rate increased. Compost rates of 10 and 20 tons/acre produced a significantly greater number of fruit $(\mathrm{P}<0.05)$ than the control (Figure 1.2).

Both shoot $(\mathrm{P}=0.0012)$ and root $(\mathrm{P}=0.0199)$ dry biomass differed among compost treatments. Dry shoot biomass was significantly greater $(\mathrm{P}<0.05)$ in plots receiving 10 or 20 tons/acre than in plots without compost amendments. Dry root biomass was significantly greater $(\mathrm{P}<0.05)$ in plots receiving 20 tons/acre than in plots receiving 2.5 tons/acre. However, neither dry root biomass nor root length (data not shown) in plots receiving no compost amendments differed significantly from plots receiving compost amendments at 20 tons/acre (Figures 1.3 and 1.4).

Compost also had a significant effect $(\mathrm{P}=0.0406)$ on disease severity, but the relationship was not linear. Disease severity tended to be higher in the 2.5 and 5 tons/acre treatments than the control and treatments with 10 and 20 tons/acre (Figure 1.5). However, due to variability in one treatment, differences were not significant according to Tukey's HSD test, despite the significant difference in the ANOVA. Differences among treatments in disease severity were apparent by mid-August and remained consistent for the remainder of the season (Figure 1.6). The GLAR rating was essentially the inverse of disease severity rating: high disease severity correlated with low percent GLAR. GLAR in the treatment with 2.5 tons/acre was significantly lower $(\mathrm{P}<0.05)$ than in the treatment with 20 tons/acre (Figure 1.7). 


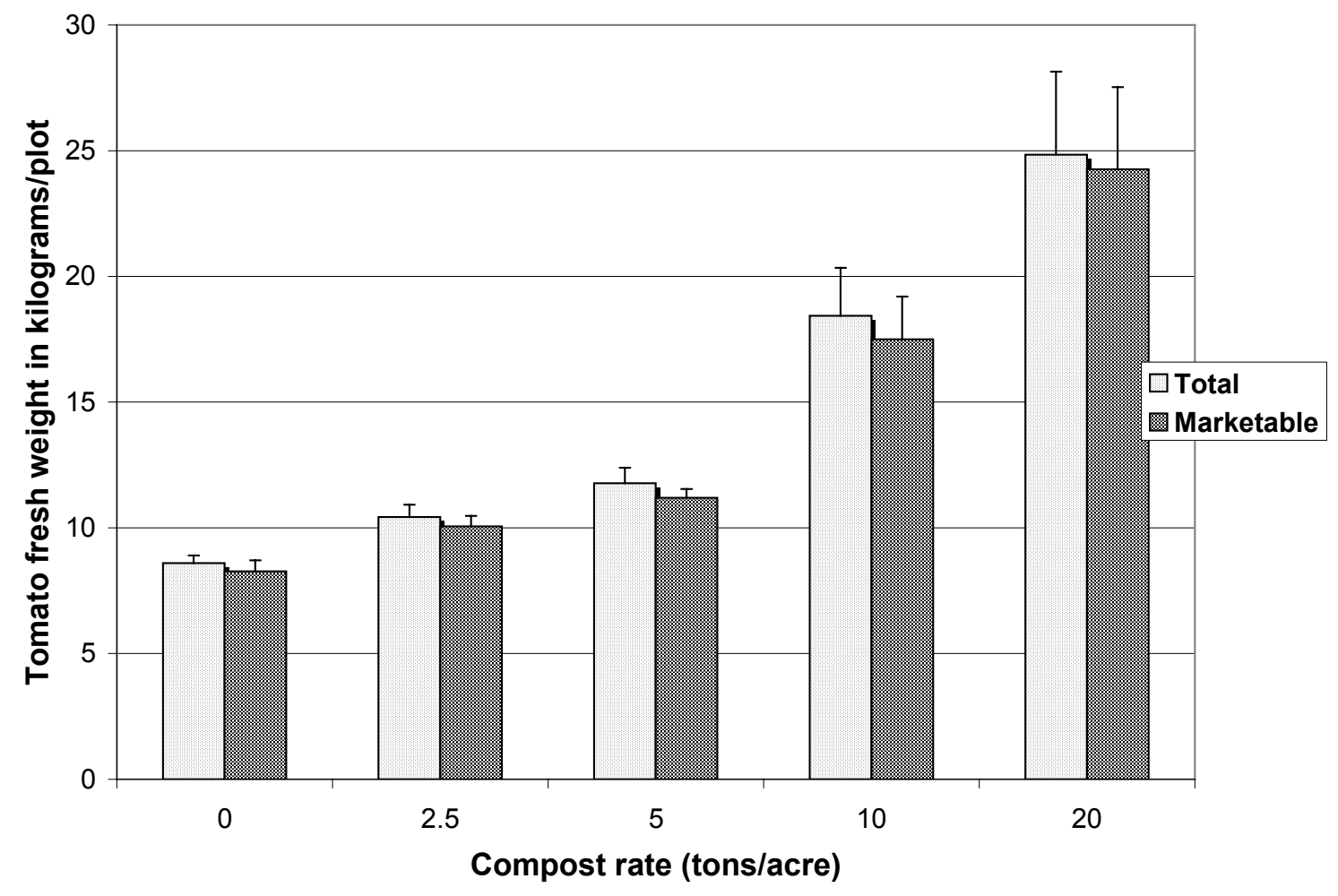

Figure 1.1. Mean (and standard error) of total and marketable fruit yield at five compost rates. Ripe fruit were harvested weekly, and all ripe and nonripe fruit were harvested at the end of the season. Fruit with cracks, holes, rot, or other blemishes were rated nonmarketable. 


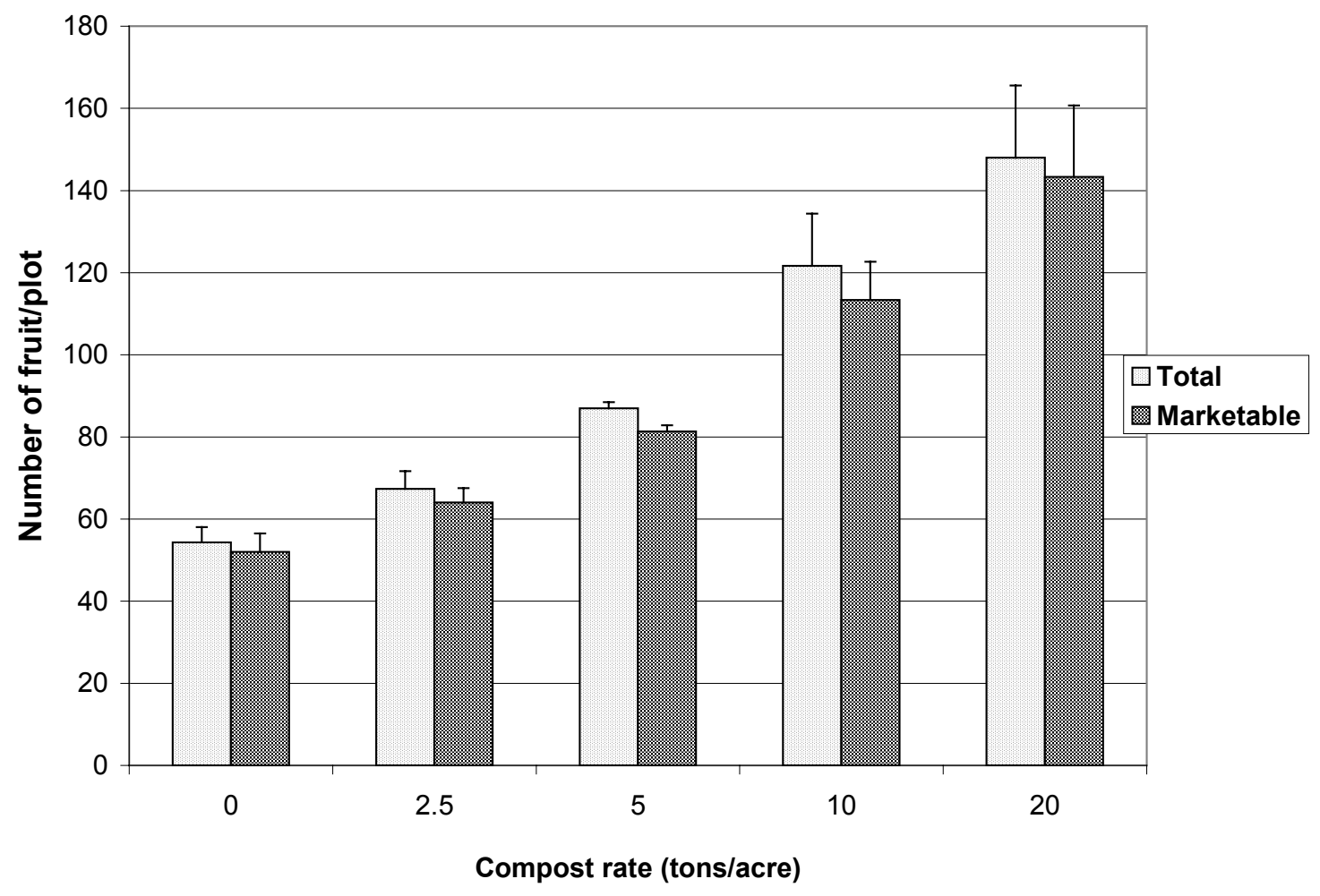

Figure 1.2. Mean number (and standard error) of total and marketable fruit per plot at five compost rates. Ripe fruit were harvested weekly, and all ripe and nonripe fruit were harvested at the end of the season. Fruit with cracks, holes, rot, or other blemishes were rated nonmarketable. 


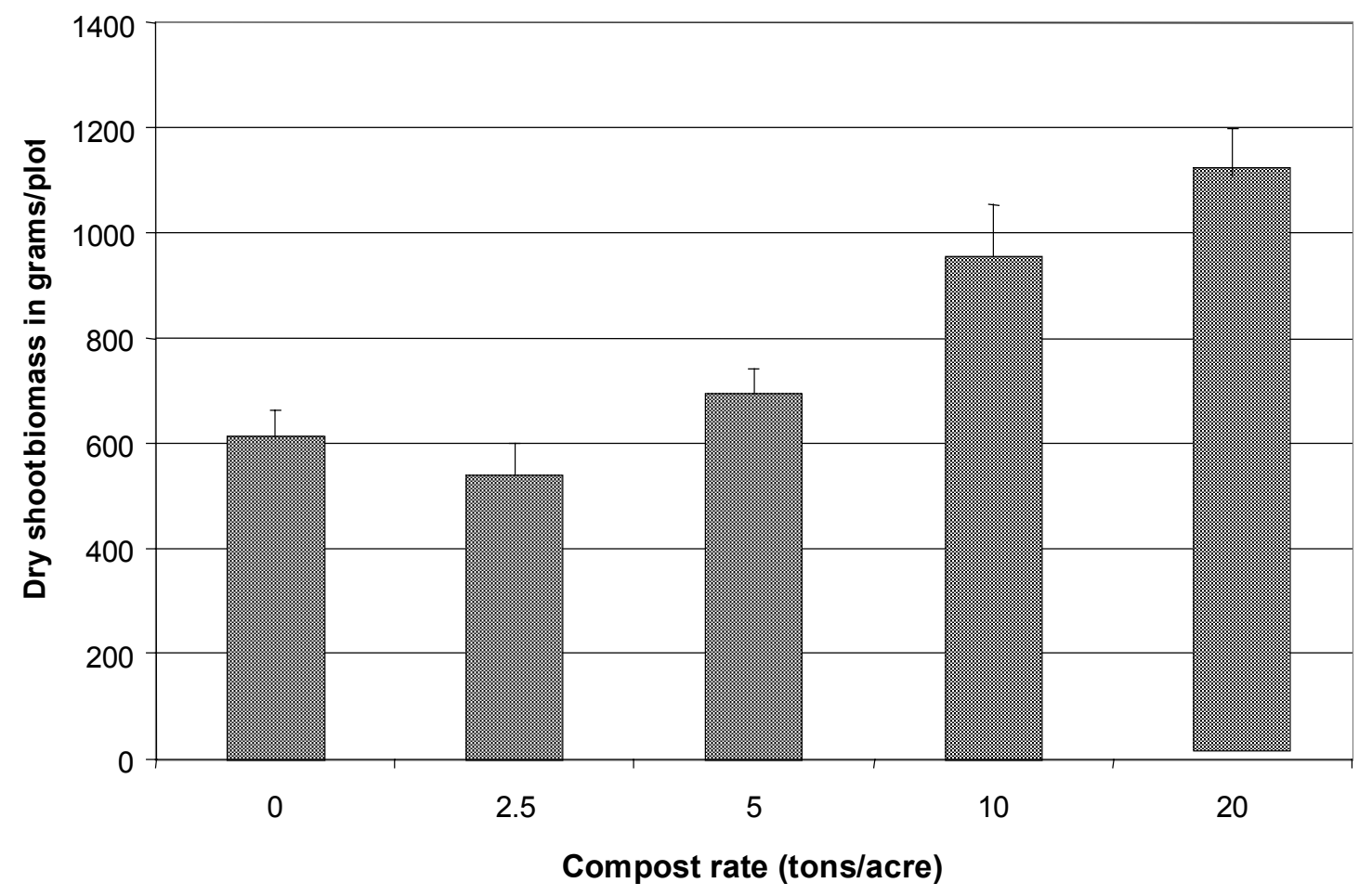

Figure 1.3. Mean tomato dry shoot biomass (and standard error) at five compost rates. Means represent 3 replicates per compost rate treatment with 4 plants per plot. 


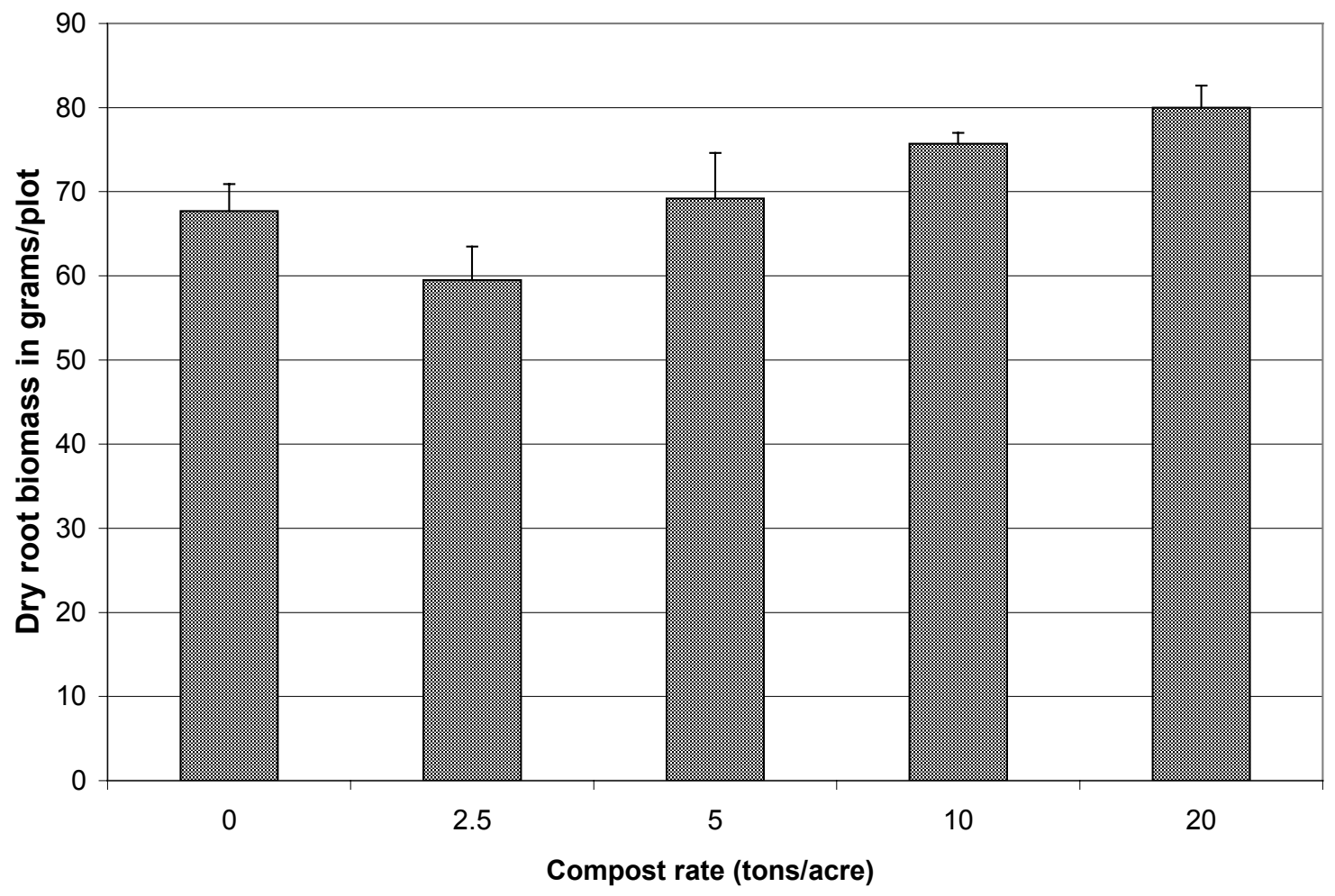

Figure 1.4. Mean tomato dry root biomass (and standard error) at five compost rates. Means represent 3 replicates per compost rate treatment with 4 plants per plot. 


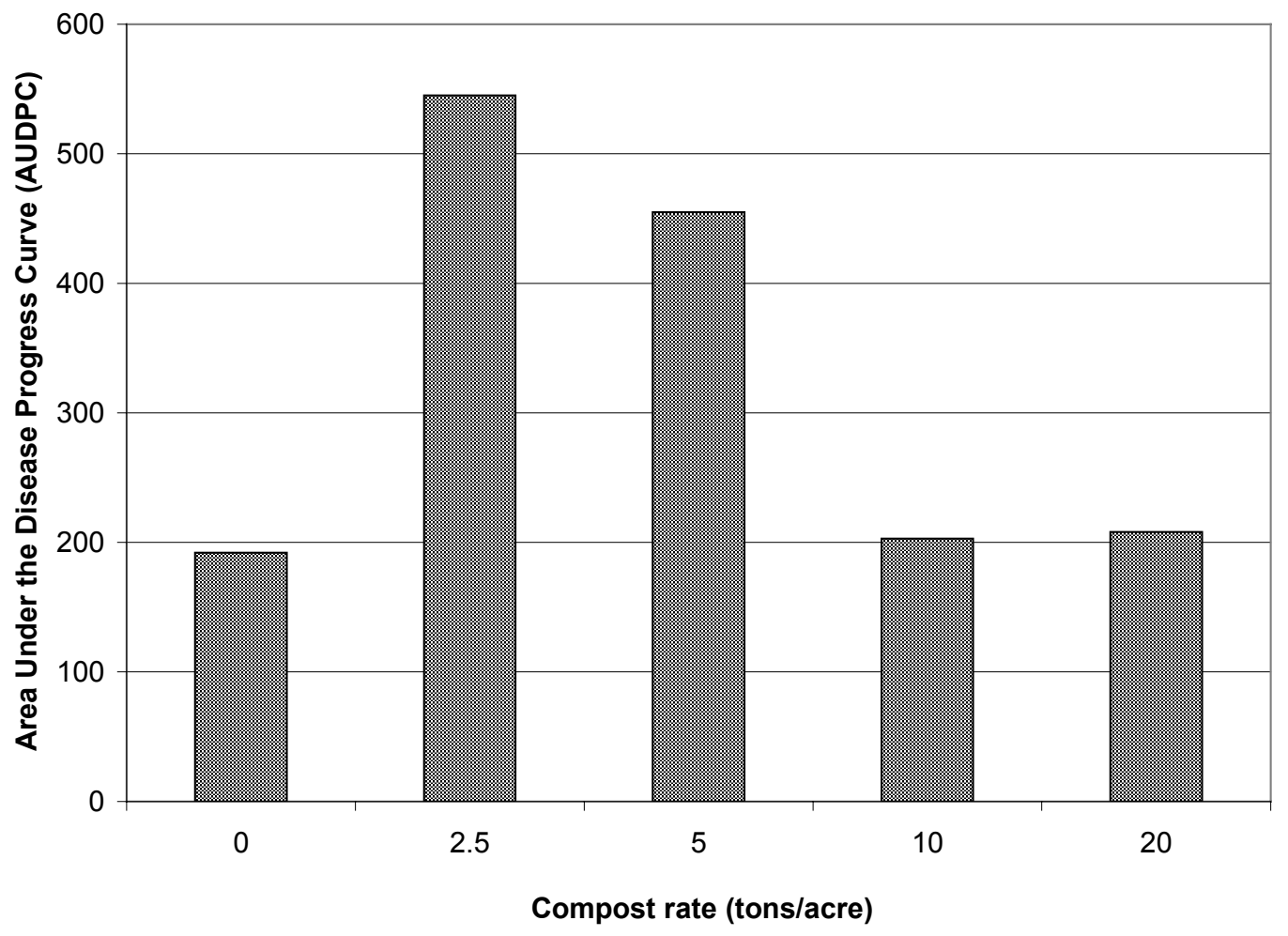

Figure 1.5. Cumulative disease severity over time expressed as $\underline{\text { Area }} \underline{\text { Under the Disease Progress }}$ Curve (AUDPC). Symptomatic tissue was estimated weekly as percent of the total leaf area of 4 tomato plants per plot. AUDPC was calculated by summing over the season the products of the number of days between disease severity ratings times the rating on that date. 


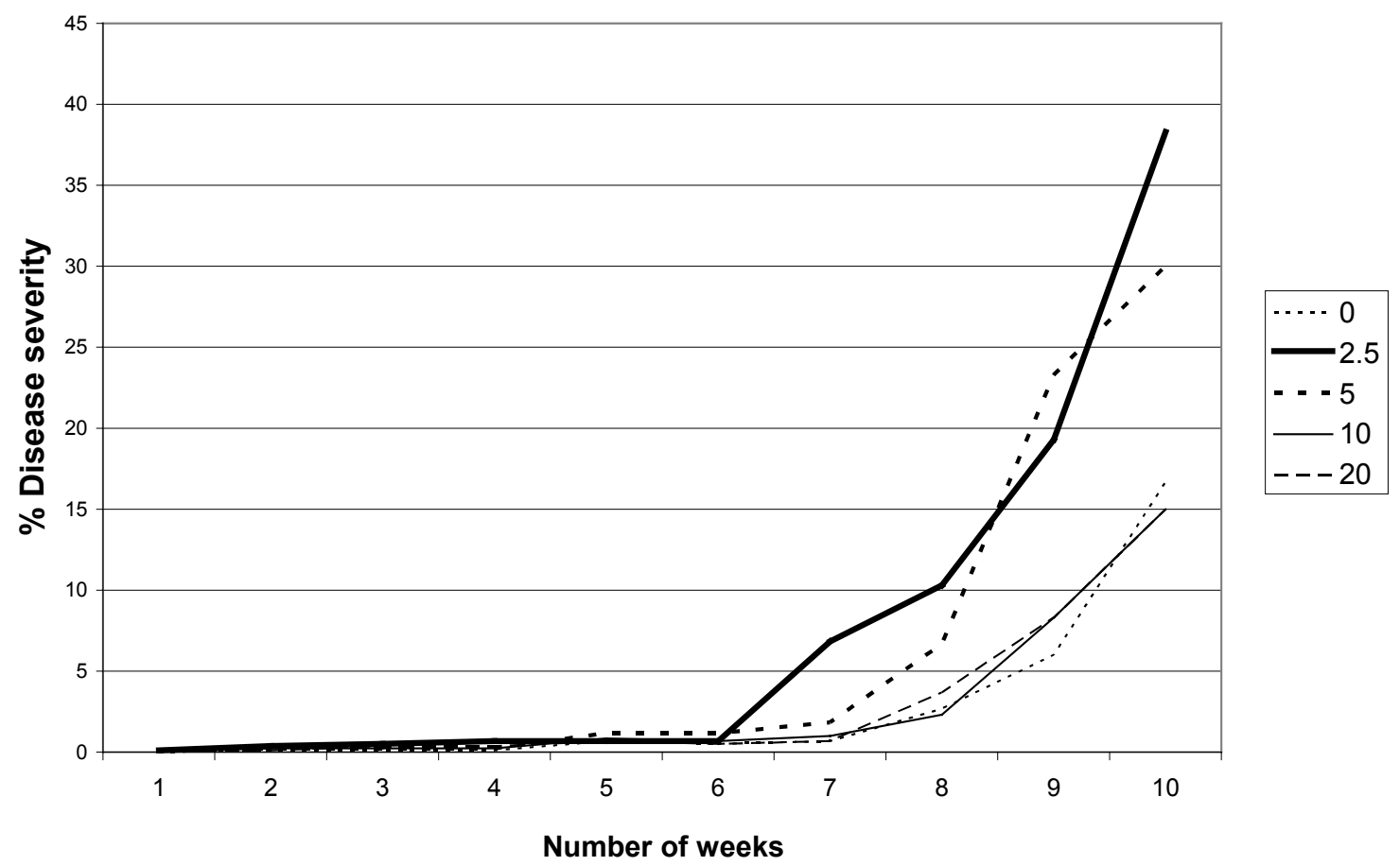

Figure 1.6. Lines indicate percent total disease in tomato plants by treatment over ten weeks. Symptomatic tissue was estimated weekly as percent of the total leaf area of 4 plants per plot over 10 weeks. 




Figure 1.7. Percent green leaf area remaining (GLAR) on tomato plants estimated weekly over 4 weeks. Mean and standard error of 3 replicates per treatment with 4 plants per plot. 


\section{Discussion}

The control treatment with no compost amendments had small plants with low fruit yield. Each compost rate increase resulted in greater fruit production. The overall trend was similar for shoot and root biomass. The only exception to the trend of increased biomass with increasing compost rate occurred in the 2.5 tons/acre treatment where shoot and root biomass were lower than in the control. However, the differences between these two treatments were not significant.

The control and 10 and 20 tons/acre treatments had similar disease levels. Disease severity did not limit fruit production in any of the treatments. Plants in the control treatment did not appear to exhibit nutrient deficiency symptoms in terms of leaf discoloration, but were small and did not form a closed canopy. The four compost treatments, by contrast, apparently had sufficient nutrients for a closed or partly closed canopy which possibly prolonged leaf wetness periods and resulted in a more favorable microclimate for disease development (Moore, 1942). The high compost rate treatments may have combined favorable conditions for the pathogen with sufficient overall plant vigor to limit disease development. The partly closed canopy in the two low compost rate treatments created similar microclimatic conditions favoring the pathogen, but a more limited nutrient supply left the plants more susceptible to disease late in the season and may have resulted in a more pronounced disease epidemic.

These results confirm an earlier study which showed similar early blight severity in tomato plots amended with a high rate of spent mushroom compost and control plots with no compost (MacNab and Beyer, 1996). Similarly, a field study by Zitter and Wolfe (1989) found no significant effect of soil nitrogen (supplied by chemical fertilizer) on early blight severity. However, urea applied as a foliar spray in the same study significantly reduced early blight defoliation, and the response was most pronounced in treatments which received the least nitrogen fertilizer.

The results of this experiment contrast, however, with a greenhouse study on control of Rhizoctonia solani with vermicompost in which cucumber seedling disease severity decreased with each 
increase in percentage of compost in the potting mixture (Wright et al., 1999). They also differ from a field study comparing the effects of composted sewage sludge at 7 tons/acre with a no compost control in which early blight was significantly higher in the control (McGovern and Obreza, 1993).

A similar trend was apparent in the GLAR data in the final four weeks of the experiment. High disease severity in the low compost rate treatments correlated with low GLAR ratings. Despite large differences in plant size, the control and treatments with 10 and 20 tons/acre of compost had similarly low disease levels and high GLAR ratings late in the season. While disease severity was higher in treatments with 2.5 and 5 tons/acre, disease pressure apparently occurred late enough that fruit yield was not affected. However, the premature defoliation associated with high disease severity might have reduced end-of-season biomass in the 2.5 tons/acre treatment compared to the control.

Compost applied at 2.5 and 5 tons/acre increased disease severity, but it did not reduce fruit yield or significantly reduce dry shoot or root biomass in the treatment with 2.5 tons/acre compared to that in the no compost treatment. Disease pressure came late in the season with sustained wet conditions in early September. Comparable conditions earlier in the season might have resulted in greater disease-induced defoliation in the treatments with 2.5 and 5 tons/acre and the loss of fruit production.

Barclay et al. (1973) state that conventional fertilizers should be used to optimize yield and argue that the additional amounts needed to manage disease would not be cost effective. The same may be true for organic growers, but depends on the cost of compost as an input. The results of this experiment suggest that compost amendments to soil in organic tomato production can boost fruit yield and reduce disease severity if applied beyond a certain threshold. The data indicate that threshold occurred between 5 and 10 tons/acre of compost under the field conditions of this experiment. The inconsistent results reported in the literature suggest that the compost rate that optimizes yield and disease suppression is probably specific by compost, crop, and host/pathogen relationship. 
CHAPTER 2: EFFICACY OF COMPOST EXTRACT

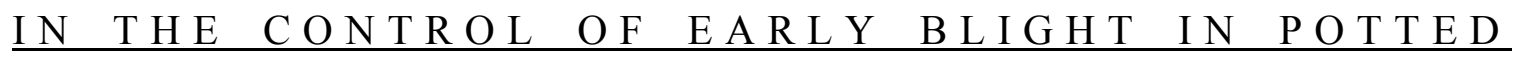
TOM A T O PLA N T S

\section{Introduction}

Water extracts of compost are widely used among organic growers for both disease suppression and fertilization through foliar feeding. Compost tea can be produced by either aerated or nonaerated methods. The latter has a longer history and more documentation as a method of plant disease control (Weltzien, 1991). While nonaerated methods are simpler and less expensive, aerated methods have been the focus of much research over the past decade and use continuous aeration to ensure aerobic conditions in the water/compost mixture. Multiple compost tea brewing equipment designs are now commercially available and in use (Scheuerell and Mahaffee, 2002).

Nonaerated production methods typically use longer brewing times. Compost is added to water in an open container with initial stirring of the mixture. The mixture stands for at least three days and up to two weeks (Brinton et al., 1996). Some practitioners and researchers call for intermittent stirring of the mixture while others leave it undisturbed over the brewing period. Compost tea prepared by either method is usually applied to plants with conventional spray equipment following straining to remove solids that would clog delivery systems.

Foliar diseases that have been controlled by nonaerated compost tea (NCT) were reviewed prior to the recent surge of interest in aerated compost teas (ACT) (Weltzien, 1991) and also summarized recently (Scheuerell and Mahaffee, 2002). Research on ACT is more recent with much anecdotal support for disease control but few controlled, replicated studies (Chalker-Scott, 2001).

The general mechanisms proposed to explain how compost might reduce disease levels also apply to compost tea:

1. Competitive inhibition: application of compost extract promotes a diverse microflora that limits the ability of pathogenic spores to germinate

2. Antibiosis: compounds produced by the microbial community in the extract inhibit the growth of or destroy pathogens 
3. Predation/parasitism: direct attack of infective propagules by microbial antagonists

4. Chemical inhibition: nonbiological compounds in the extract inhibit the pathogen

5. Induced resistance: activation of latent resistance mechanisms in plants by pathogens, chemicals, or beneficial microorganisms

One or several mechanisms may play a role for a specific type of disease suppression with a particular compost extract. Chemical factors such as $\mathrm{pH}$ and nutrient levels can affect disease severity by altering conditions that favor either the host plant or the pathogen (Boulter et al., 2002). Evidence that the microbial community plays a key role is supported by a number of studies in which the sterilizing or filtering of extracts is shown to reduce or eliminate disease suppressive properties (Weltzien and Ketterer, 1986; Craft and Nelson, 1996; Zhang et al., 1998). Inoculating sterilized or filtered extracts with untreated extracts restores both the microbial community and disease suppressive properties. This restoration indicates biological factors at work, but the mechanism could still involve competitive inhibition, antibiosis, predation/parasitism, induced resistance, or some combination of mechanisms. Reduction of the microbial community has inconsistent effects on loss of disease suppression. A study of compost extract effects on the apple scab pathogen Venturia inaequalis found a large reduction in germination of the pathogen conidia compared to germination in water controls (Cronin et al., 1996). Autoclaved compost extracts were less suppressive of disease than untreated extracts but retained most of their efficacy. Disease suppression with the spent mushroom compost they used was at least partly chemical and not strictly biological in nature: a low molecular weight, heat-stable metabolite produced by anaerobic microorganisms in the compost appeared to play some role.

Zhang et al. (1998) found that foliar application of a water extract of compost reduced the severity of bacterial speck on Arabidopsis thaliana plants compared to plants sprayed with a water control and suggested systemic acquired resistance (SAR) as a possible mechanism in the study. However, it remains unknown how compost might induce an SAR response. Granatstein (1999) by contrast reported no disease suppression by compost tea applied to apple, cherry, peach, and grape crops compared to a water only control treatment.

Scheuerell and Mahaffee (2002) reviewed research with NCT on tomato bacterial speck that showed significant but inconsistent control. Seven-day-old NCT made from pine bark, cow manure, and yard waste composts had variable efficacy within batches of the same compost source. A heat- 
stable metabolite produced in the compost appeared to suppress this bacterial disease. A study of NCT on tomato late blight showed reduced suppressiveness to in vitro infection of tomato with progressively finer filtration of the extract. Disease suppression was lost from filtrates from sieves

of less than 10-micrometer-pore size. Scheuerell and Mahaffee (2002) identify CT brewing and application parameters that should be specified for clarity and consistency in continuing CT research. These include compost feedstock, age, compost to water ratio, brewing time, additional nutrients (if any) added, surfactant use, and application timing.

Few studies have directly compared disease control obtained with aerated versus nonaerated compost teas. In this greenhouse study, CT was prepared by both methods from seven composts derived from various feedstocks and was applied as a foliar spray to two tomato cultivars. Incidence of early blight, caused by Alternaria solani, was compared by treatment and cultivar in a series of seven experiments.

\section{Materials and Methods}

The two tomato cultivars used in these experiments, 'Brandywine' and 'WV '63', were grown from seed in potting mix (Sunshine ${ }^{\circledR}$ Professional Growing Mix \#1, Sun Gro Horticulture, Canada) in $15-\mathrm{cm}$ pots under standard greenhouse conditions. After approximately 60 days of growth, plants at blossom stage were assigned to eight treatments with six replicates of each. Seven treatments were tap water extracts (CT) of composts from different feedstocks: dairy, horse, and poultry manure, hay, spent mushroom waste, and yard waste. The seventh treatment was a vermicompost manure compost processed by earthworms. Tap water served as the control treatment in each experiment.

The seven composts were analyzed by the West Virginia Department of Agriculture Nutrient Management Lab in Moorefield, WV for nutrient analysis and carbon:nitrogen ratio (Appendix, Table 2.1).

CT was made using aerated and nonaerated processes for 48 hours. Tap water used for extracts stood for 24 hours prior to the brewing process to permit the degassing of chlorine. The water to compost ratio for extracts was 10:1 by volume. In the nonaerated process, compost was initially stirred vigorously into water in $0.95-\mathrm{L}$ plastic containers. The mixture was stirred a second time 
prior to spray application on plant leaves. In the aerated brewing process, air was circulated through the mixture with an electric pump (EPI P-380 Aquarium Air Pump) for 48 hours.

The fungal pathogen, Alternaria solani, provided by the Department of Plant Pathology at Cornell University, was cultured on V8 agar and divided every ten days to ensure a steady supply of sporulating material. Two-week-old fungal colony surfaces were washed with distilled water and gentle brushing action to collect spores. Spore concentration was measured with a hemocytometer and the water volume adjusted to standardize the concentration at 20,000 spores $\mathrm{ml}^{-1}$ for spray inoculation.

Seven experiments were performed, each with six replicate plants for each CT treatment. Individual leaves on plants were the experimental units for measuring disease severity. Even-age plants were used in each experiment with the treatment leaf standardized in each case. Six plants sprayed with tap water served as the positive control treatment in each experiment. Within each treatment, the fourth oldest leaf on each plant served as a negative noninoculated and untreated control. These negative control leaves were enclosed in ziplock bags for protection from CT treatment and pathogen inoculation.

The cultivar ' $\mathrm{WV}$ ' 63 ' was used in experiments 1, 3, 6, and 7 and 'Brandywine' in experiments 2 and 5. Both cultivars were compared in experiment 4. Experiments 1 to 3 tested NCT while experiments 4 to 7 used ACT.

CT treatments were applied one time to the third oldest leaf on each plant in experiments 1 to 4 and to the third and fifth leaves in experiments 5 to 7 . The CT was filtered through screen mesh into a plastic spray bottle and sprayed onto leaf surfaces until run-off. After one hour when leaves had dried, leaf surfaces were spray inoculated with a suspension of Alternaria solani containing 20,000 spores $\mathrm{ml}^{-1}$. Treated and inoculated leaves were then enclosed in ziplock bags for 12 hours to provide humid conditions for spore germination and penetration.

Plants were moved from a greenhouse to a separate classroom for CT treatment and inoculation and remained there for the duration of each experiment. This was done in order to isolate experimental plants and to avoid pathogen contamination in the greenhouse. Ambient temperatures were similar in both locations, but light level was considerably lower in the classroom. 


\section{Statistical Analysis}

Data were analyzed using a one-way ANOVA. Where a significant F-value was found, Tukey's HSD $(\mathrm{P}<0.05)$ was used to compare treatment means in disease severity. In experiment 4 , a twoway ANOVA was used to test for interaction between main effects of compost tea and cultivar.

\section{Results}

\section{Nonaerated}

Disease developed slowly in experiment 1 with early blight lesions appearing 3 days after inoculation. Most negative control leaves (leaf 4) had no disease symptoms (data not shown). Disease development was slow enough that disease was rated at 4, 8, and 12 days after inoculation. Differences among treatment means were marginally significant $(\mathrm{P}=0.0917) 8$ days after inoculation, but not after 4 or 12 days (Figure 2.1). Leaves treated with mushroom CT had the highest and leaves treated with yard waste CT the lowest disease severity after 8 days.

Disease developed more rapidly in experiments 2 and 3 with early blight lesions appearing 2 days after inoculation. Most control leaves had no disease symptoms (data not shown). In experiment 2, CT had a significant effect $(\mathrm{P}=0.0001)$ on disease severity at 4 days after inoculation. Disease severity in the yard waste $\mathrm{CT}$ treatment was higher $(\mathrm{P}<0.05)$ than for the control, hay $\mathrm{CT}$, and dairy CT treatments (Figure 2.2).

Trends in experiment 3 were similar to experiment 2 . Disease severity differed significantly among CT treatments after 4 and 8 days $(\mathrm{P}=0.0006$ and $\mathrm{P}=0.0477$, respectively). Hay $\mathrm{CT}$, dairy $\mathrm{CT}$, horse $\mathrm{CT}$, and vermiculture CT resulted in lower disease severity than the tap water control after 4 days, and the difference was significant $(\mathrm{P}<0.05)$ for hay CT. Five treatments produced $100 \%$ disease severity after 8 days (Figure 2.3). 


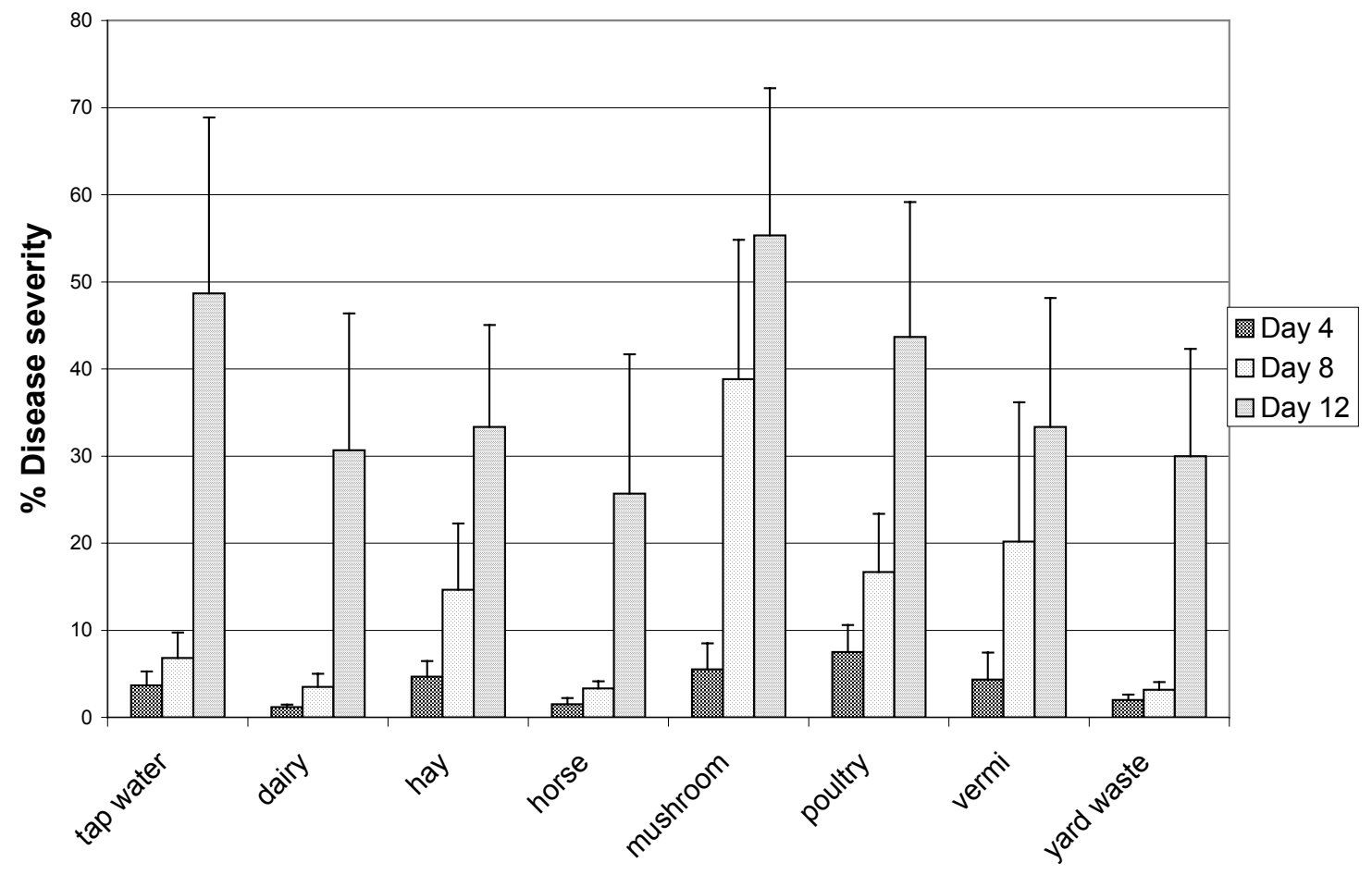

Figure 2.1. Experiment 1 with NCT: percent disease severity on individual 'WV ' 63 ' tomato leaves treated with compost tea and spray inoculated with a spore suspension of $A$. solani. Treated leaves were the third oldest on each plant and disease severity was rated 4, 8, and 12 days after inoculation. Mean and standard error of 6 replicates. 


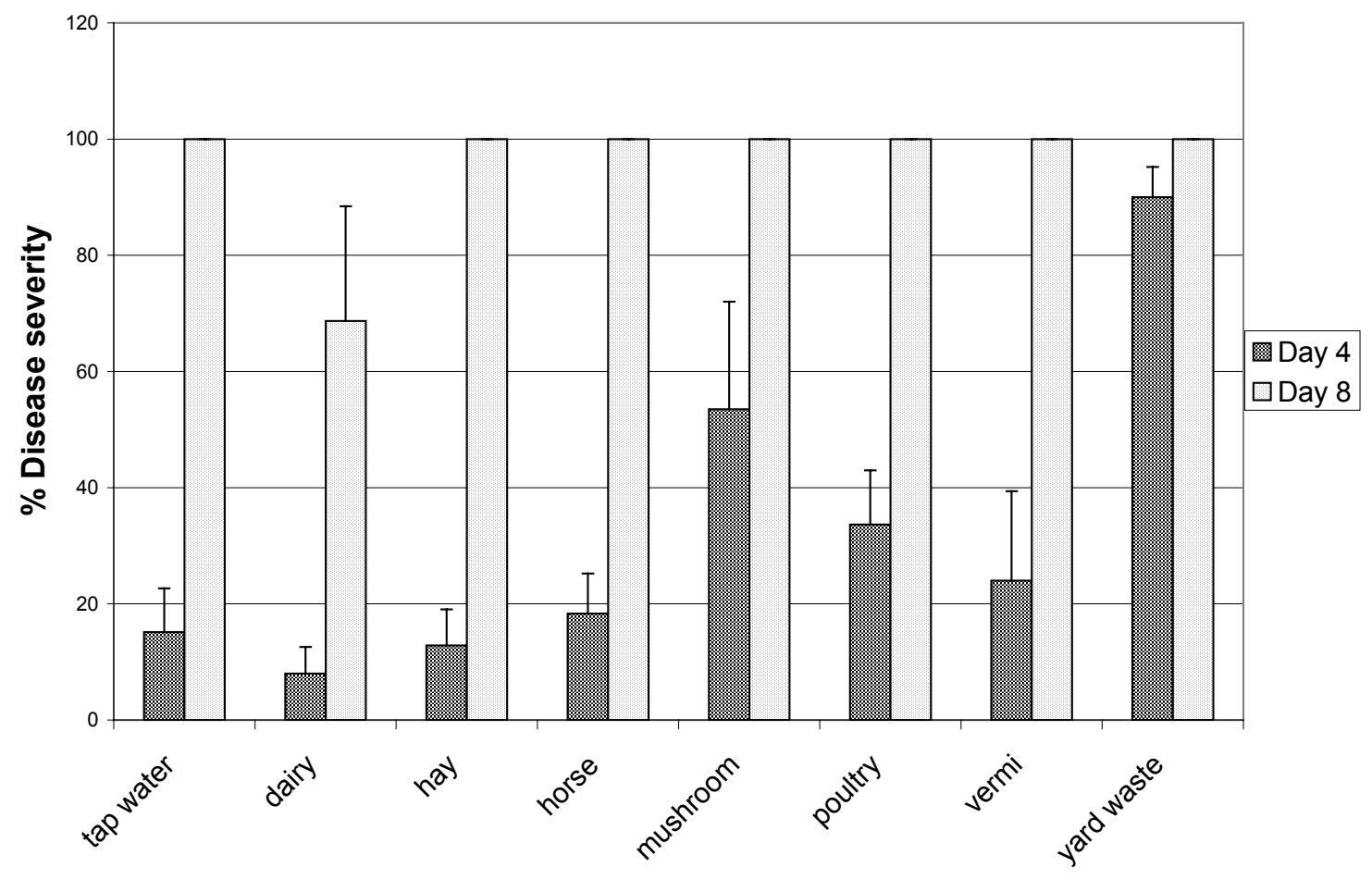

Figure 2.2. Experiment 2 with NCT: percent disease severity on individual 'Brandywine' tomato leaves treated with compost tea and spray inoculated with a spore suspension of $A$. solani. Treated leaves were the third oldest on each plant and disease severity was rated 4 and 8 days after inoculation. Mean and standard error of 6 replicates. 


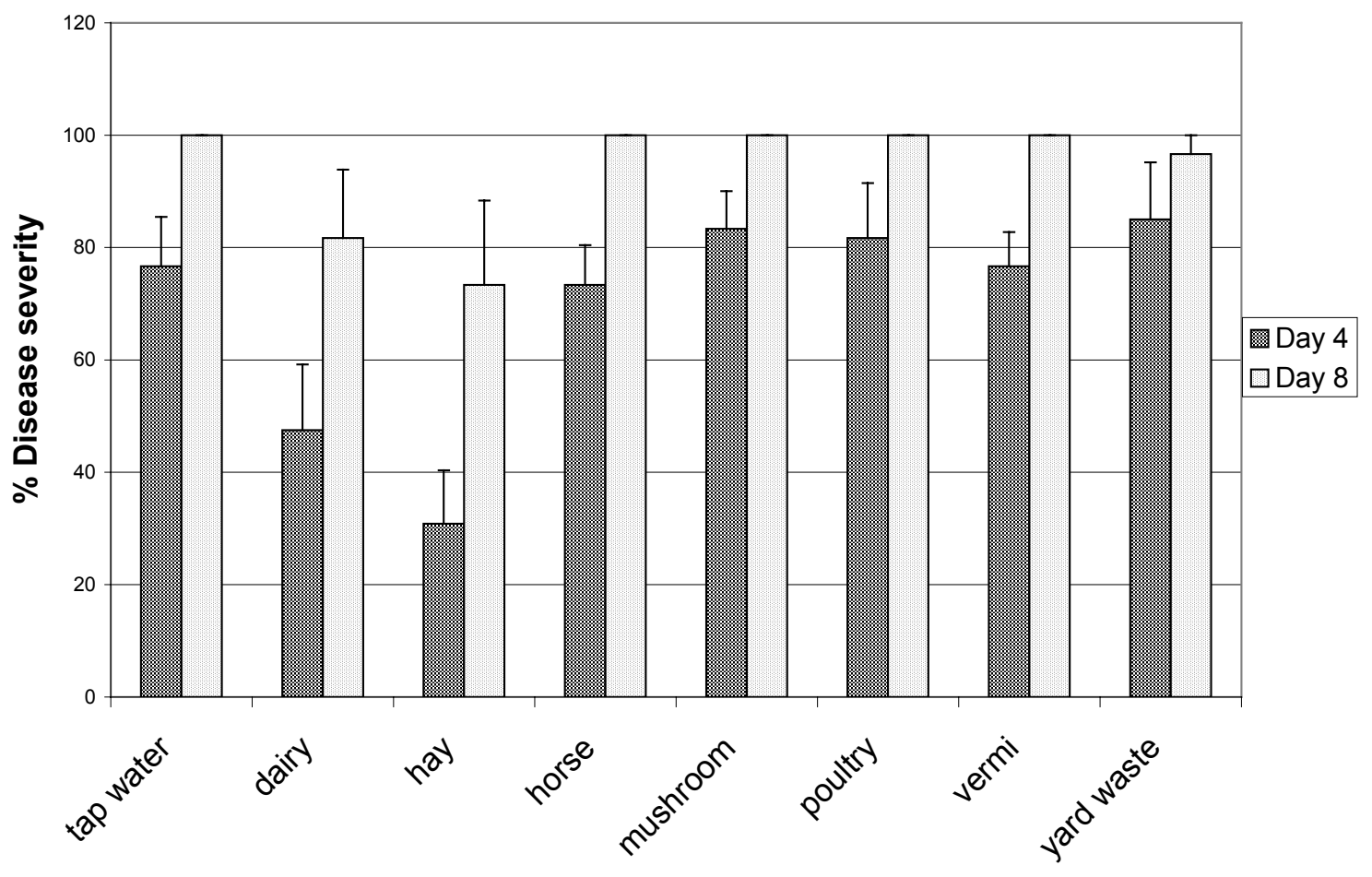

Figure 2.3. Experiment 3 with NCT: percent disease severity on individual 'WV ' 63 ' tomato leaves treated with compost tea and spray inoculated with a spore suspension of $A$. solani. Treated leaves were the third oldest on each plant and disease severity was rated 4 and 8 days after inoculation. Mean and standard error of 6 replicates. 


\section{Aerated}

In experiment 4 there was no significant effect of $\mathrm{CT}$ on disease severity. The interaction between CT and cultivar was not significant, but cultivar had a pronounced effect: disease severity was significantly higher $(\mathrm{P}=0.0001)$ for 'Brandywine' (mean=76.2\%) than for 'WV '63' (mean= $40.2 \%)$.

In experiments 5, 6, and 7, disease developed more rapidly on third than on fifth leaves. Early blight lesions were visible at 2 days after inoculation on third leaves and at 3 days after inoculation on fifth leaves. Most negative control leaves had no disease symptoms (data not shown).

CT had a significant effect on disease severity in experiment 5 on third and fifth leaves $(\mathrm{P}=0.0249$ and $\mathrm{P}=0.0027$, respectively) after 4 days (Figure 2.4). Third leaves treated with hay $\mathrm{CT}$ and fifth leaves treated with yard waste CT had significantly lower $(\mathrm{P}<0.05)$ disease severity than third and fifth leaves treated with mushroom CT.

At 8 days after inoculation in experiment 5, third leaves treated with dairy CT had the lowest disease severity, but overall differences among treatments were not significant and several treatment means converged at or near $100 \%$ disease severity. On fifth leaves CT had a significant $(\mathrm{P}=0.0013)$ effect. Leaves treated with yard waste $\mathrm{CT}$, hay $\mathrm{CT}$, and dairy $\mathrm{CT}$ had significantly lower $(\mathrm{P}<0.05)$ disease severity than leaves treated with mushroom CT (Figure 2.5).

Trends in experiment 6 were similar to experiment 5. CT had a significant effect $(\mathrm{P}=0.0001)$ on disease severity after 4 days. On third leaves disease severity was significantly lower $(\mathrm{P}<0.05)$ with yard waste, dairy, and hay CT than with poultry or mushroom CT. On fifth leaves, disease severity with mushroom $\mathrm{CT}$ was significantly higher $(\mathrm{P}<0.05)$ than on leaves treated with the control or with yard waste CT (Figure 2.6).

The CT effect was significant after 8 days on third leaves $(\mathrm{P}=0.0017)$ and on fifth leaves $(\mathrm{P}=0.0001)$. Third leaves treated with horse, mushroom, or poultry CT had significantly higher 
$(\mathrm{P}<0.05)$ disease severity than leaves treated with hay CT. Fifth leaves receiving mushroom CT also had significantly higher disease severity $(\mathrm{P}<0.05)$ than fifth leaves on plants treated with the control or yard waste CT (Figure 2.7).

In experiment 7, differences among $\mathrm{CT}$ treatments were not significant, but the overall trend continued: leaves treated with mushroom $\mathrm{CT}$ had the highest mean disease severity and leaves treated with hay CT and dairy CT generally had the lowest.

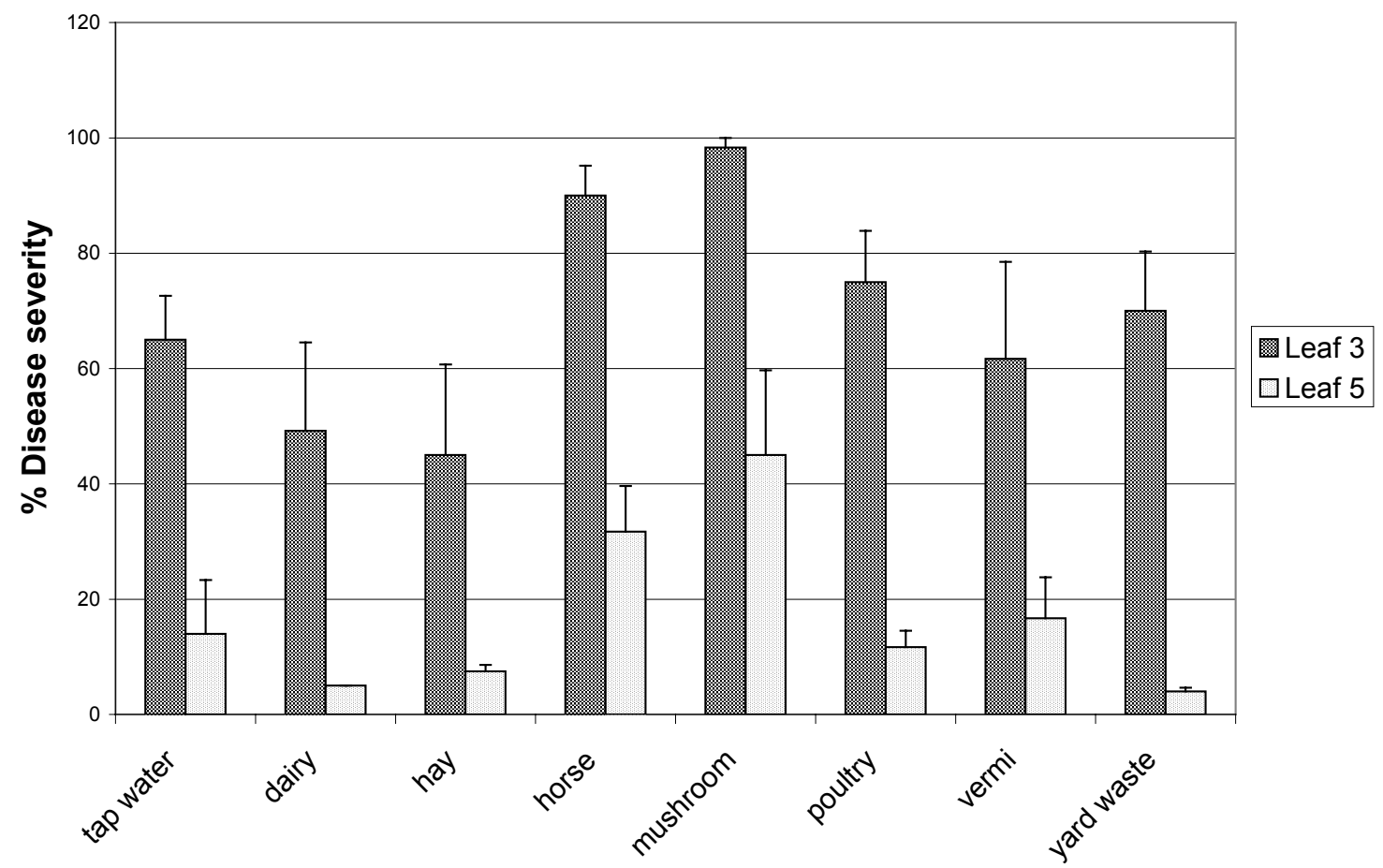

Figure 2.4. Experiment 5 with ACT: percent disease severity 4 days after spray inoculation with a spore suspension of $A$. solani on individual 'Brandywine' tomato leaves treated with compost tea. Treated leaves were the third and fifth oldest on each plant. Mean and standard error of 6 replicates. 


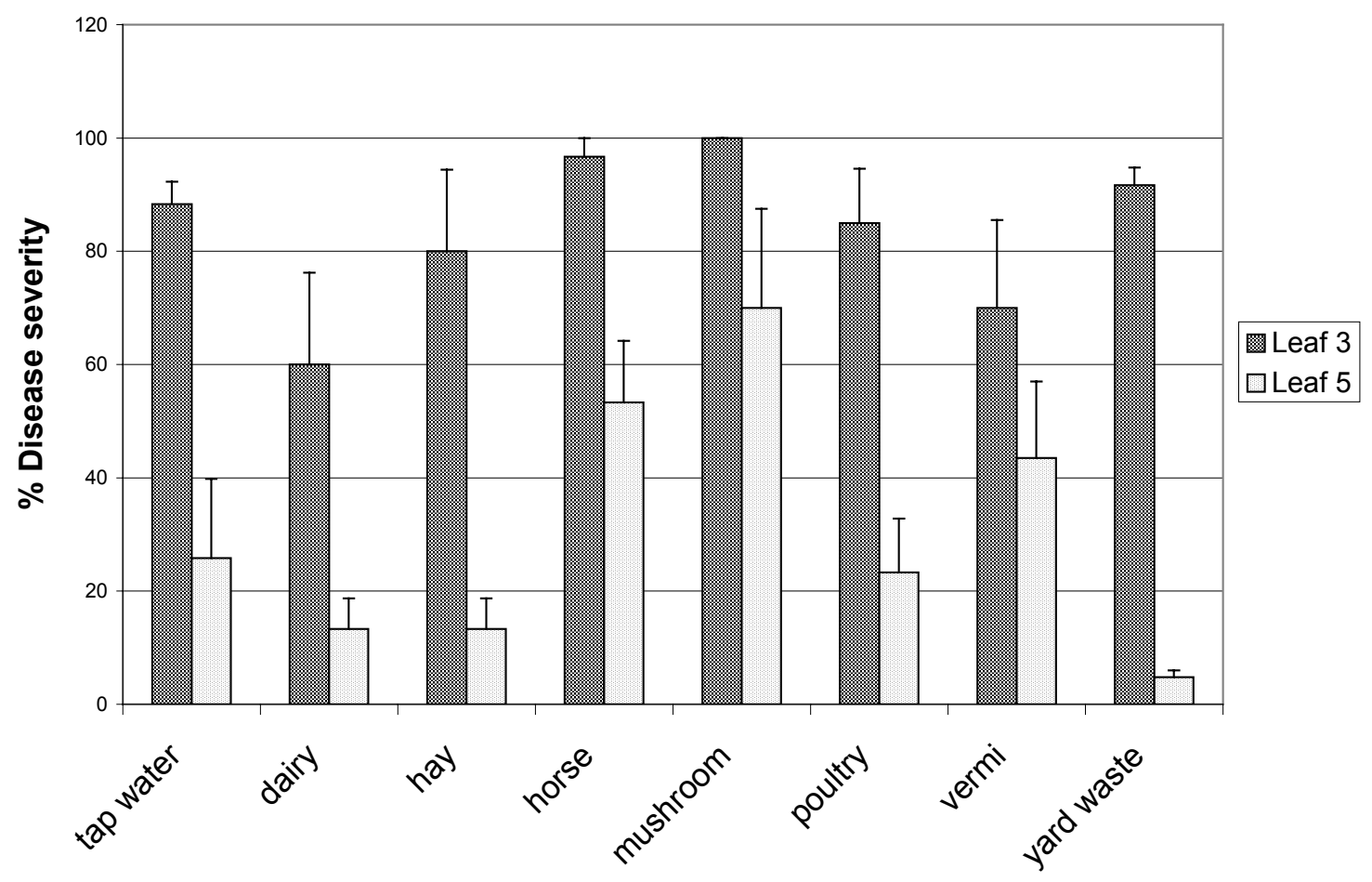

Figure 2.5. Experiment 5 with ACT: percent disease severity 8 days after spray inoculation with a spore suspension of $A$. solani on individual 'Brandywine' tomato leaves treated with compost tea. Treated leaves were the third and fifth oldest on each plant. Mean and standard error of 6 replicates. 




Figure 2.6. Experiment 6 with ACT: percent disease severity 4 days after spray inoculation with a spore suspension of $A$. solani on individual 'WV ' 63 ' tomato leaves treated with compost tea. Treated leaves were the third and fifth oldest on each plant. Mean and standard error of 6 replicates. 


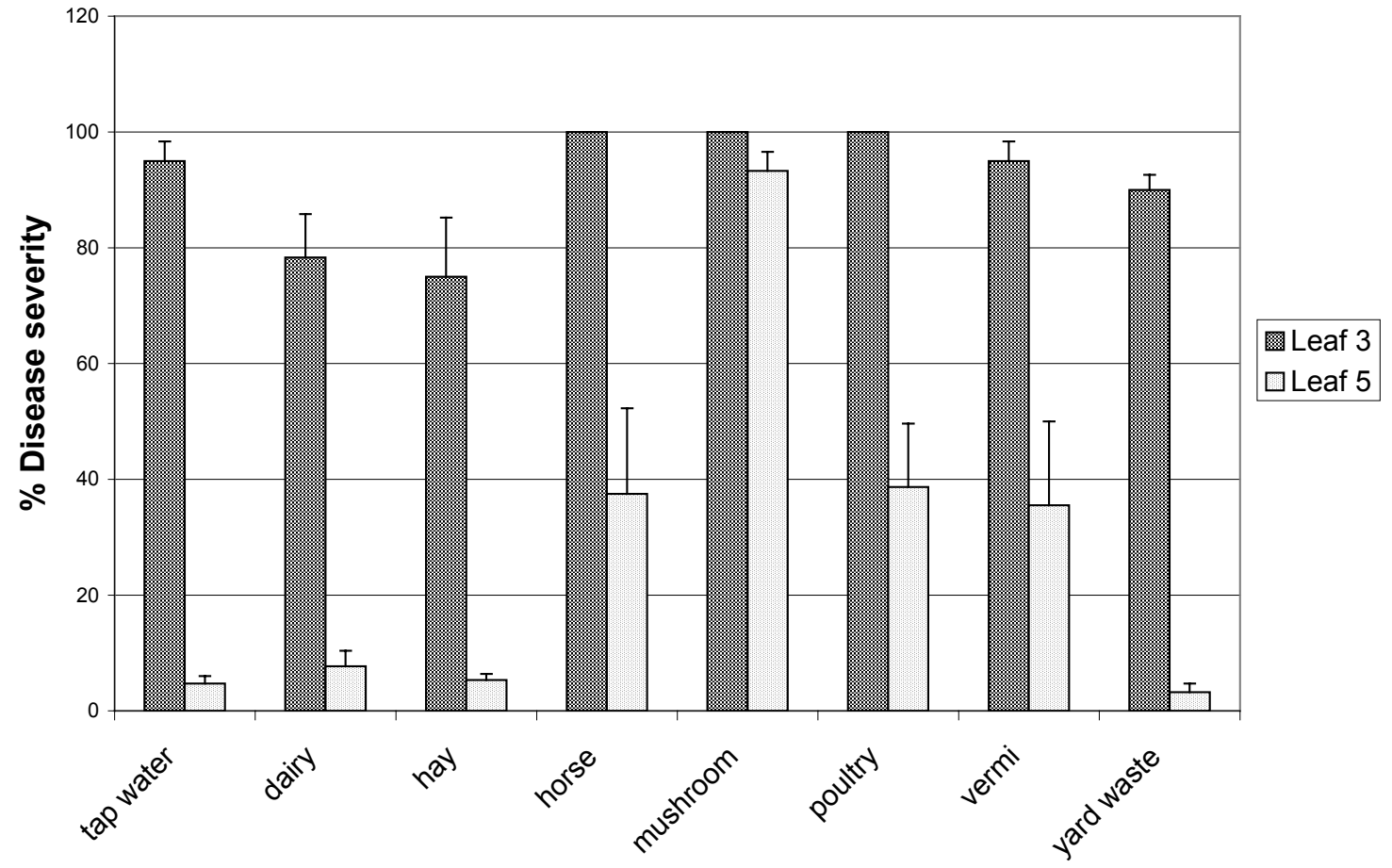

Figure 2.7. Experiment 6 with ACT: percent disease severity 8 days after spray inoculation with a spore suspension of $A$. solani on individual 'WV ' 63 ' tomato leaves treated with compost tea. Treated leaves were the third and fifth oldest on each plant. Mean and standard error of 6 replicates. 


\section{Discussion}

The potted plants were moved in the course of the research, subjecting them to stress and injury lesions which could not consistently be distinguished from disease lesions. Plant age differed among the first three experiments. Experiment 1 plants were 57 days old at inoculation while plants in experiments 2 and 3 were 64 and 67 days old respectively. The difference of 7 or 10 days in age may partly explain why disease development was considerably slower in experiment 1 . Rapid disease development made disease rating problematic when disease severity for several treatments converged at or near $100 \%$ eight days following inoculation. Older leaves are more susceptible to infection by the fungal pathogen A. solani. Slower disease development on fifth leaves helped discriminate treatment differences. The data in the final three experiments indicate that younger leaves are more useful for separating treatment means and comparing treatment effects than older leaves. The fifth oldest leaf of each plant was a better choice than the third oldest leaf.

NCT application to plant leaves in three experiments resulted in treatment differences for disease severity, yet only in experiments 2 and 3 were these differences significant. The tap water control treatment ranked intermediate in disease severity, with NCT treatment means in some cases above and sometimes below the control mean. Hay and dairy manure NCT generally had the lowest mean disease severity, and hay NCT was significantly lower than the control in experiment 3. Where clear treatment separation occurred, mushroom, poultry, and yard waste NCT generally had the highest mean disease levels. Disease severity for yard waste NCT was significantly higher than the control in experiment 2 . Variability was very high among all treatments.

ACT application to plant leaves in four experiments also affected disease severity, with some treatments differing significantly from the control. A consistent result was high disease severity associated with mushroom ACT. Plants treated with mushroom ACT had the highest disease severity in most experiments, and were significantly higher than the control in experiment 6 . Hay, dairy manure, and yard waste CT treatments generally reduced disease severity compared to the control which was intermediate among the 8 treatments.

The consistent increase in disease severity with mushroom compost tea was an unexpected result. This result is striking since the agronomic goal of CT application is disease reduction. Some 
compound in the water extract of the mushroom compost appeared to either favor the pathogen or independently cause leaf necrosis which was mistaken for early blight symptoms.

Disease severity ratings were highly variable in all seven experiments, particularly for yard waste CT which resulted in both the highest (experiments 2 and 3) and lowest (experiments 1, 6, and 7) disease severity levels. This inconsistent result cannot be explained as a function of aeration because low disease severity ratings with yard waste CT occurred in experiment 1 and high ratings occurred in experiments 2 and 3.

Disease control is the main goal of research on CT. Inconsistent results in these seven experiments confirm previous studies on many crops and diseases: successful control has been achieved yet the record is mixed and mechanisms are unclear. Composts vary greatly due to both feedstock and composting process. There can also be considerable variability within a single batch of compost. This lack of uniformity poses challenges for research. The small amount of compost for CT brewing was well below the 500-gram minimum recommended (Yohalem et al., 1996) to avoid sampling error. Still, for six of the seven treatments, associated disease severity can be ranked high for mushroom CT and low for dairy and hay CT. Significant disease reduction compared to the control occurred only with hay CT in experiment 3, yet both hay and dairy CT showed a strong tendency to reduce disease severity. Both CT formulations show some agronomic potential for disease management and merit further study. 


$\begin{array}{llllll}\text { CHAPTER } & 3: & \text { EFFECT S OF OMPOST }\end{array}$
AMENDMENTS AND COMPOST EXTRACTS ON THE INCIDENCE OF FOLIAR DISEASE IN ORGANIC TOMATO PRODUCTION

\section{Introduction}

Compost soil amendments and compost teas (CT) are widely used in organic agriculture and are believed to promote plant health. A general bibliography on compost for disease control has been compiled by Ringer (1998). Research on compost tea is more recent and has been reviewed by Weltzien (1991) and Scheuerell and Mahaffee (2002). Most studies on compost soil amendments focus on root diseases while CT research generally emphasizes foliar disease. The two modes of compost use have always been investigated separately rather than jointly in a single experiment. Likewise, few studies directly compare aerated compost tea (ACT) with nonaerated compost tea (NCT) for efficacy in disease control. This research examines the combined effects of compost soil amendments and foliar spray and directly compares ACT with NCT. Two field experiments were conducted to test the hypothesis that compost as a soil amendment or foliar spray can reduce early blight severity in organic tomato production. A 2002 experiment (experiment 1) tested 10 compost treatments with and without the corresponding tea to evaluate their interactions. The potential interaction is of practical interest because organic growers who produce their own CT would typically make it from the same compost they apply to their soil. Three soil treatments and five CT treatments arranged in all combinations were tested in 2004 (experiment 2); in four of these fifteen combinations, the CT applied to foliage was derived from the same compost used as the soil amendment. 


\section{Materials and Methods}

Tomato cultivar 'WV 63' was used in both experiments and the research conducted at the West Virginia University Organic Research Farm in Morgantown, WV. Soil at the site was a Dormont silt loam. Plants were inoculated with a spore suspension of Alternaria solani. The fungal pathogen (original isolate provided by the Department of Plant Pathology at Cornell University) was cultured on V8 agar and divided every ten days to assure a steady supply of sporulating material. Two-weekold fungal colony surfaces were washed with distilled water and gentle brushing action to collect spores. Spore concentration was measured with a hemocytometer and the water volume adjusted to standardize the concentration at 20,000 spores $\mathrm{ml}^{-1}$ for spray inoculation.

\section{Experiment 1: Initial Compost Screen}

This field experiment consisted of 10 compost treatments with and without the corresponding compost tea in a split plot design. Compost treatments were applied to four replicate whole plots, $2.7 \times 4.5 \mathrm{~m}$, arranged in a random complete block design, and tilled in prior to planting tomato cultivar 'WV ' 63 '. The compost treatments were:

1. Seneca ${ }^{\circledR}$ (composted horse manure and wood shavings)@3.3 dry tons/acre

2. commercial dairy manure compost (contents not described)@3.3 dry tons/acre

3. spent mushroom waste compost @3.3 dry tons per acre

4. Premium ${ }^{\circledR}$ (composted dairy manure and pine shavings) @3.3 dry tons/acre

5. municipal yard waste compost @3.3 dry tons/acre

6. WVU composted dairy manure and yard waste @ 3.3 dry tons/acre

7. WVU composted dairy manure and yard waste @ 10 dry tons/acre

8. composted hardwood bark@3.3 dry tons/acre

9. composted hardwood bark@3.3 dry tons/acre and blood meal @ 60 lbs. N/acre 10. blood meal (control)@6 lbs.N/acre

Nitrogen, phosphorus, and potassium analyses were $0.25 \%-0.14 \%-0.20 \%$ for Seneca ${ }^{\circledR}, 2.1 \%-0.3 \%$ $0.72 \%$ for Premium ${ }^{\circledR}$, and $0.57 \%-0.82 \%-0.46 \%$ for the WVU dairy manure compost, respectively.

Tomato transplants were grown in a peat/composted dairy manure/perlite potting medium in the greenhouse and 8-week-old plants were transplanted to the field plots on June 4. Eighteen plants per 
plot were spaced $0.75 \mathrm{~m}$ apart in three rows with $0.9 \mathrm{~m}$ between rows. Plots were mulched one week later with hay on a single layer of newsprint and trellised three weeks after transplanting.

CT was prepared for each plot from the same compost added to the soil. Tap water for compost tea stood for 24 hours prior to CT brewing to allow for the degassing of chlorine. Fine mesh fabric bags containing solid compost were suspended for 48 hours in 19-L buckets at a 10:1 water to compost ratio. Two ml of the surfactant Nu-Film-17 (Miller Chemical \& Fertilizer Co., Hanover, PA) were added to improve spreading and sticking of the liquid to leaf surfaces. One randomized subplot in each plot was sprayed with $\mathrm{CT}$ and the other subplot was sprayed with tap water as a control. Sprays were applied weekly from August 13 to September 3 with a Solo backpack sprayer. Lower leaves of two corner plants in each plot were spray inoculated with $4 \mathrm{ml}$ of a spore suspension of the Alternaria solani on August 12 and September 3 to promote disease development.

Disease severity, yield, and plant biomass data were collected from the center two plants in each subplot. Disease incidence was measured weekly from July 26 to October 5 by estimating necrotic area as percentage of total leaf area on data plants. A single independent estimate of percent green leaf area remaining (GLAR) was made October 18. Ripe or nearly ripe fruit were harvested weekly from August 24 to October 12. Total number of fruit and total weight were recorded by subplot. Plants were cut at ground level on October 20 and oven-dried at $54^{\circ} \mathrm{C}$. for 4 days to determine dry shoot biomass.

\section{Experiment 2: Compost and Compost Tea Interactions}

Three soil amendments and five CT treatments were arranged in all combinations in a completely randomized $3 \times 5$ factorial design, with 6 replications for a total of 90 plots. Soil amendments were analyzed by the West Virginia Department of Agriculture Nutrient Management Lab in Moorefield, WV for nutrients and carbon:nitrogen ratio (Table 3.1) and added to plots prior to planting. The three soil amendments were: dairy manure compost from the WVU Animal Science Farm, municipal yard waste compost from Clarksburg, West Virginia, and blood meal as the control. 
Table 3.1. Compost and blood meal nutrient analysis

\begin{tabular}{|l|l|l|l|l|l|l|l|l|}
\hline $\begin{array}{l}\text { Soil } \\
\text { amendment }\end{array}$ & $\begin{array}{l}\text { C:N } \\
\text { ratio }\end{array}$ & \%N & \%P & \%K & \%NH & \%Cu & \%Ca & \%Mg \\
\hline $\begin{array}{l}\text { Dairy manure } \\
\text { compost }\end{array}$ & 18.66 & 0.48 & 0.56 & 0.32 & 0.04 & 0.0002 & 1.02 & 0.10 \\
\hline $\begin{array}{l}\text { Yard waste } \\
\text { compost }\end{array}$ & 32.32 & 0.56 & 0.39 & 0.18 & 0.09 & 0.0001 & 1.23 & 0.07 \\
\hline Blood meal & $\mathrm{x}$ & 12 & $\mathrm{y}$ & $\mathrm{y}$ & $\mathrm{y}$ & $\mathrm{y}$ & $\mathrm{y}$ & $\mathrm{y}$ \\
\hline
\end{tabular}

${ }^{\mathrm{x}}$ No ratio reported.

${ }^{\mathrm{y}}$ No analysis reported for this nutrient.

Dairy manure and yard waste composts were applied at 10 tons dry weight per acre (approximately $100 \mathrm{lbs}$. N) and blood meal was applied to supply approximately $150 \mathrm{lbs}$. N per acre. Soil amendments were distributed evenly in each plot and incorporated by rototiller. Each experimental unit consisted of $1.5 \times 1.8-\mathrm{m}$ plots with two rows of two plants each. Compost tea was applied to four data plants, with two unsprayed plants providing a buffer between adjacent plots in a bed. Spacing was $0.75 \mathrm{~m}$ between rows and $0.6 \mathrm{~m}$ between plants. Beds of ten adjacent plots were separated by $1.9-\mathrm{m}$ grass alleys.

Tomato transplants were grown for 8 weeks in the greenhouse in a peat/composted dairy manure/perlite potting mix and were transplanted to the field June 3 and 4. Each plant was individually staked the following week and the bed rows mulched one week later with a single layer of newsprint covered by hay. The grass alleys between plots were mowed four times for weed and insect control. Plants were tied to stakes as the stems elongated. Weeding and hand-picking for tomato hornworm control was conducted weekly as the plants matured. 
Five spray treatments were applied to foliage weekly beginning July 7 . These were: dairy manure ACT, dairy manure NCT, yard waste ACT, yard waste NCT, and tap water as the control. CT applied weekly from each compost source was prepared by aerated and nonaerated processes. In both processes, municipal tap water stood for 24 hours prior to brewing to allow the degassing of chlorine.

Nonaerated: Solid compost was suspended in loose mesh plastic bags in 19-L buckets of water at a 10:1 ratio of water to compost by volume. After 48 hours the liquid was strained and $2 \mathrm{ml}$ of the surfactant $\mathrm{Nu}$-Film-17 were added to improve spreading and sticking of the liquid to leaf surfaces. CT was applied to plants with a Solo backpack sprayer.

Aerated: Solid compost was suspended in loose, plastic mesh onion bags in 114-L containers of water at a 10:1 ratio of water to compost. Air was bubbled from the bottom of the containers with a small, electric pump (Ethical Products, Inc., EPI P-380 Aquarium Air Pump) over the 48-hour brewing period. Forty liters of compost tea were prepared in each container, and $4 \mathrm{ml}$ of the surfactant Nu-Film-17 were added before CT was applied to plants. Twenty liters of undiluted extract were initially applied to 72 plants in each treatment group. As the plants grew, the rate was increased to $24 \mathrm{~L}$ per 72 plants (approximately 180 liters per acre). CT was applied to whole plants until run-off with an emphasis on the lower half most susceptible to early blight infection.

Eight leaves of similar age were harvested from each plot on July 9, aggregated by treatment, and frozen. Tissue analysis for total carbon, nitrogen, and sulfur was done October 27 with a $L E C O$ CNS-2000 (Laboratory Equipment Corporation, St. Joseph, MI).

\section{Disease Inoculation and Monitoring}

All 180 buffer plants were inoculated on July 23 and then weekly from August 6 to September 3 with $4 \mathrm{ml}$ of a 20,000 spore $\mathrm{ml}^{-1}$ suspension of $A$. solani applied by spray bottle to lower leaves late evenings or early mornings during sustained leaf wetness periods that favored fungal spore germination. Weekly disease monitoring began July 22 and continued through September 16. Total visible lesions were initially counted on all four data plants while disease severity was very low. As disease increased, severity was estimated by lesion surface area as percentage of total leaf area. Disease severity was visibly higher on buffer than on data plants within a week, but the disease development on data plants was slow despite repeated inoculations of buffer plants. Plant stems 
were cut flush at the soil surface on October 8. Four plants from each plot were combined, ovendried at $43^{\circ} \mathrm{C}$. for 9 days, and the shoot biomass weighed and recorded.

\section{Statistical Analysis}

In experiment 1, a split-plot ANOVA was used to determine the significance of the main effect of compost and the tea-within-compost effect. Because no tea was applied in the blood meal-only plots, the design was unbalanced. Where a significant F-value was found, Tukey's HSD was used to compare treatment means within a compost treatment, in order to determine whether individual compost teas had any effect compared to corresponding compost-alone treatment. A two-way ANOVA was conducted to test for interaction between main treatments in experiment 2. A completely randomized one-way ANOVA was used to determine the significance of main treatments. Tukey's HSD $(\mathrm{P}<0.05)$ was used to compare treatment means. Orthogonal contrasts were conducted to determine the effect of compost source on disease severity. Area under the disease progress curve (AUDPC) was calculated by summing over the season the products of the number of days between disease severity ratings times the rating on that date.

\section{Results}

Total dry shoot biomass, fruit weight, and fruit number differed significantly $(\mathrm{P}=0.001)$ among soil treatments in both experiments. The highest plant growth and fruit yield in experiment 1 occurred with dairy manure (DM) and yard waste (YW) composts and the lowest with hardwood bark composts and the blood meal control treatment. CT had no significant effects (Figures 3.1, 3.2, and 3.3) on plant growth or fruit yield. 


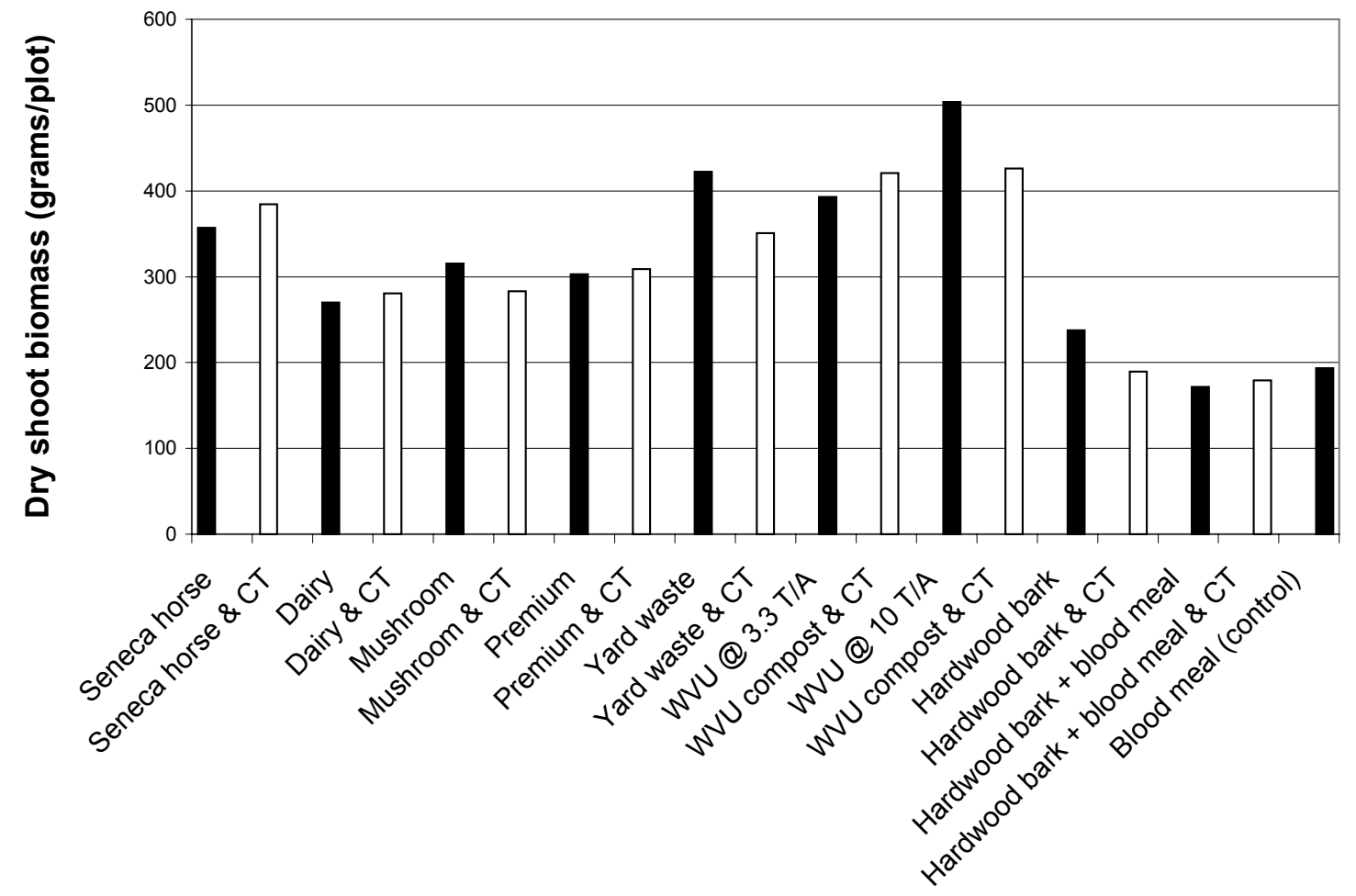

Figure 3.1. Experiment 1: dry weight in grams of tomato shoots from plots with 10 soil amendments, with or without the corresponding compost tea (CT). Means of 4 plots per treatment, with 2 plants in each plot. 


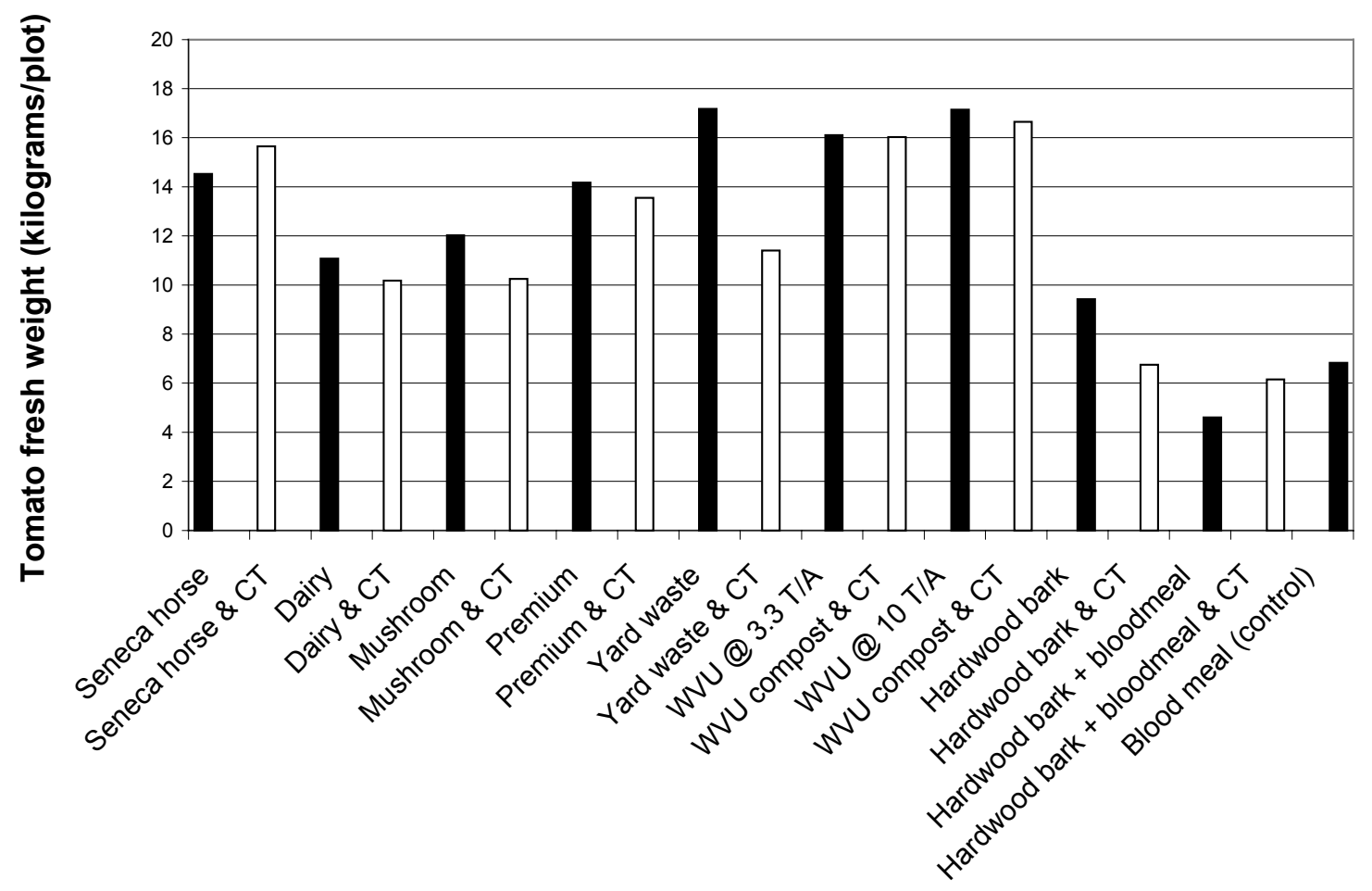

Figure 3.2. Experiment 1: fresh fruit weight in kilograms from plots with 10 soil amendments, with or without the corresponding compost tea (CT). Means of 4 plots per treatment, with 2 plants in each plot. Ripe fruit were harvested weekly and all ripe and nonripe fruit were harvested at the end of the season. 




Figure 3.3. Experiment 1: number of fruit from plots with 10 soil amendments, with or without the corresponding compost tea (CT). Means of 4 plots per treatment, with 2 plants in each plot. Ripe fruit were harvested weekly and all ripe and nonripe fruit were harvested at the end of the season.

In experiment 2, ANOVA indicated that the main effects of soil treatments on plant growth and yield were significant $(\mathrm{P}=0.001)$. Plants treated with blood meal had greater shoot biomass and fruit yield $(\mathrm{P}<0.05)$ than plants treated with yard waste compost (Table 3.2 and Figures $3.4,3.5$, and 3.6). The main effects of CT treatments on plant growth and fruit yield were not significant. The interaction of soil treatments and CT was not significant for any dependent variable measured except total fruit number $(\mathrm{P}=0.0848)$.

Aeration had a marginally significant ( $\mathrm{P}=0.0918$ according to Tukey's HSD) effect on disease 
severity in experiment 2. Lower disease severity occurred with aerated than with nonaerated CT. Soil treatment (Table 3.2) had a significant $(\mathrm{P}=0.0184)$ and $\mathrm{CT}$ a marginally significant $(\mathrm{P}=0.0974)$ effect on average percent GLAR at the end of the season. Plants treated with dairy manure compost had significantly higher $(\mathrm{P}<0.05)$ percent GLAR than plants treated with blood meal.

Table 3.2. Mean dry shoot biomass, fruit weight, and percent green leaf area remaining (GLAR) by soil treatment

\begin{tabular}{|l|l|l|l|l|}
\hline Soil Treatment & $\begin{array}{l}\text { Mean dry shoot } \\
\text { biomass (g/plot) }\end{array}$ & $\begin{array}{l}\text { Mean fruit weight } \\
\text { (kg/plot) }\end{array}$ & $\begin{array}{l}\text { Mean \% GLAR over } \\
\text { 4 weeks }\end{array}$ \\
\hline Blood meal & $738 \mathrm{a}$ & $19.0 \mathrm{a}$ & $40.6 \mathrm{~b}$ \\
\hline Dairy manure compost & $678 \mathrm{ab}$ & $13.0 \mathrm{ab}$ & $48.1 \mathrm{a}$ \\
\hline Yard waste compost & $607 \mathrm{~b}$ & $12.4 \mathrm{~b}$ & $45.3 \quad \mathrm{ab}$ \\
\hline
\end{tabular}

Means followed by the same letter do not differ significantly according to Tukey's HSD $(\mathrm{P}<0.05)$.

Since the two-way interaction was not significant, data were averaged over all soil amendments to compare compost tea treatments (Figure 3.3).

Table 3.3. Effect of compost extracts on AUDPC

\begin{tabular}{|l|l|}
\hline Compost tea & $\begin{array}{l}\text { Area Under the Disease } \\
\text { Progress Curve (AUDPC) }\end{array}$ \\
\hline Dairy manure ACT & $193 \quad \mathrm{a}$ \\
\hline Dairy manure NCT & $241 \quad \mathrm{ab}$ \\
\hline Yard waste ACT & $279 \quad \mathrm{ab}$ \\
\hline Tap water & $317 \quad \mathrm{ab}$ \\
\hline Yard waste & $346 \quad \mathrm{~b}$ \\
\hline
\end{tabular}

Means followed by the same letter do not differ significantly according to Tukey's $\operatorname{HSD}(\mathrm{P}<0.05)$ 


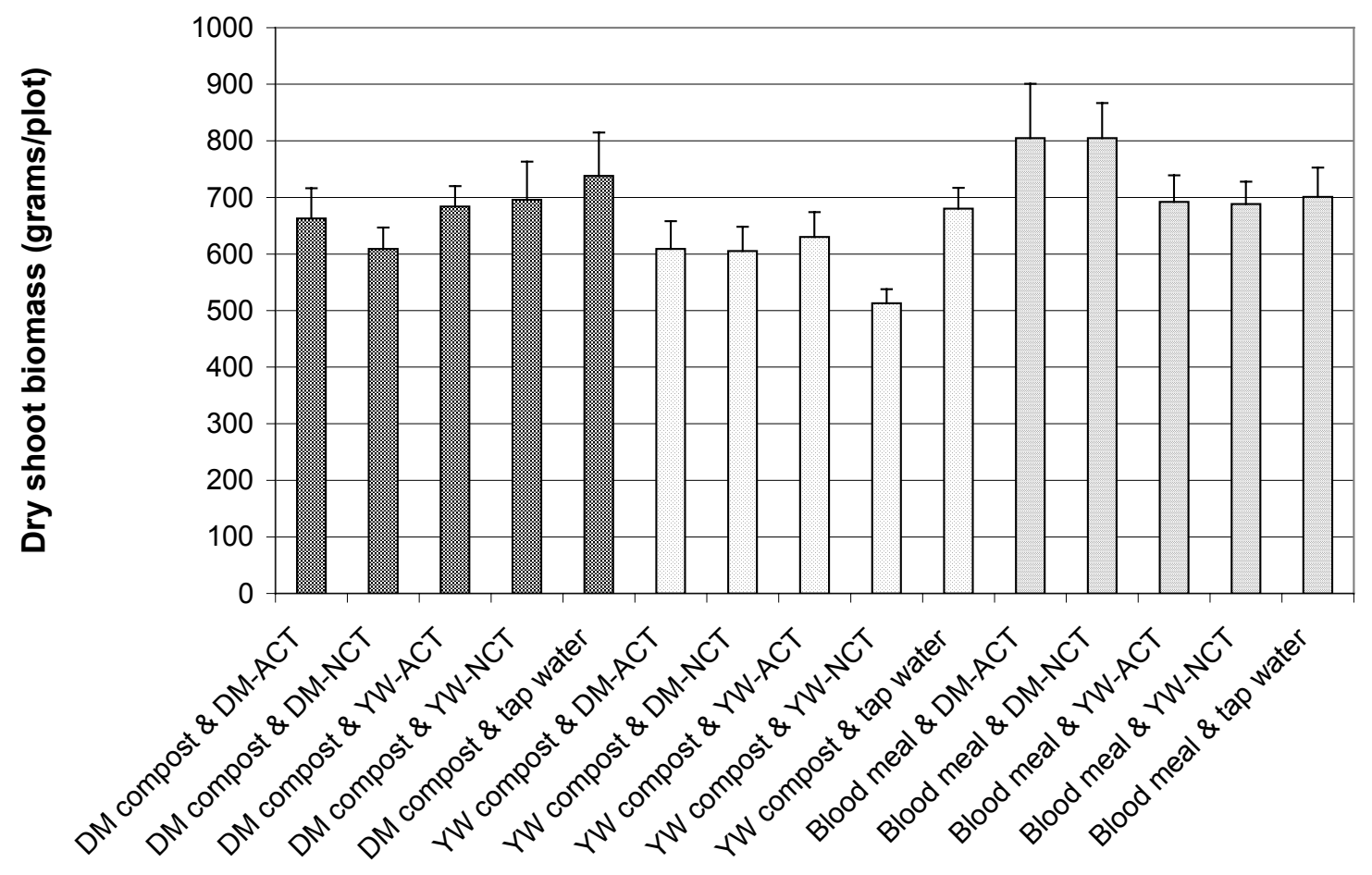

Figure 3.4. Experiment 2: dry weight in grams of tomato shoots from plots receiving dairy manure compost (DM), yard waste compost (YW), or blood meal soil amendments and sprayed with aerated (ACT) or non-aerated (NCT) compost tea. Mean and standard error of 6 replicate plots with 4 plants per plot. 


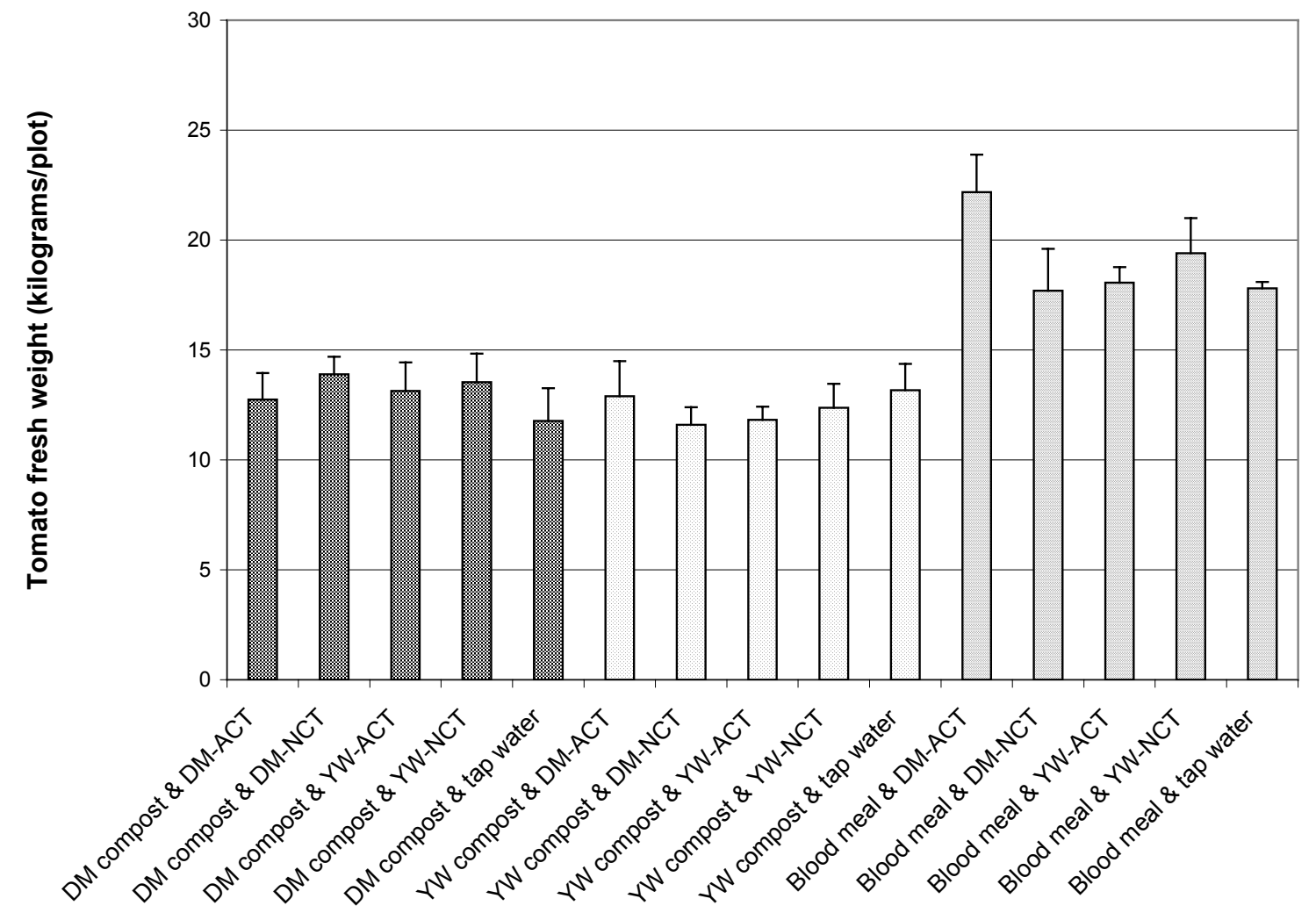

Figure 3.5. Experiment 2: weight in kilograms of fruit from plots receiving dairy manure compost (DM), yard waste compost (YW), or blood meal soil amendments and sprayed with aerated (ACT) or non-aerated (NCT) compost tea. Mean and standard error of 6 replicate plots with 4 plants per plot. Ripe fruit were harvested weekly and all ripe and nonripe fruit were harvested at the end of the season. 


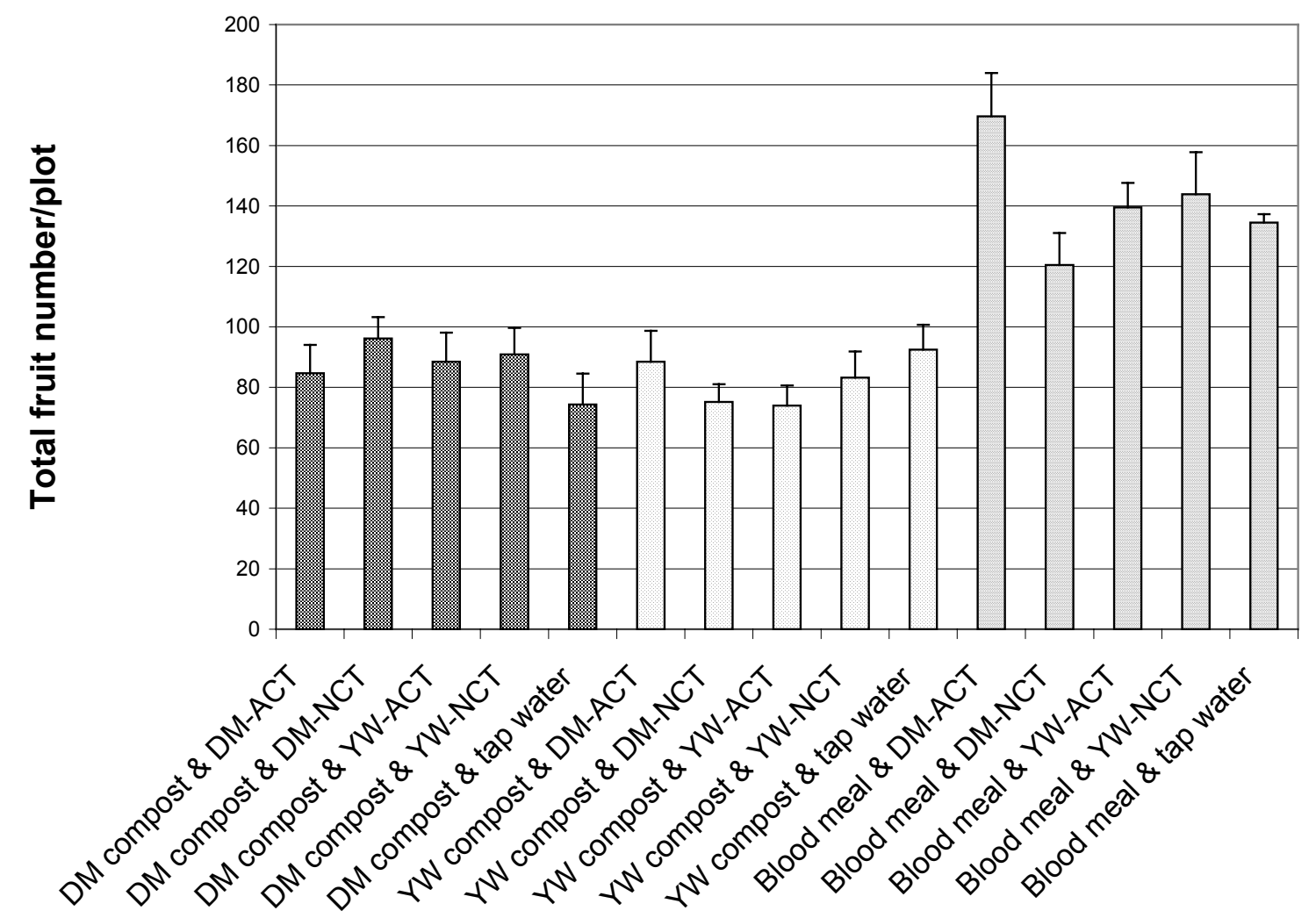

Figure 3.6. Experiment 2: number of fruit from plots receiving dairy manure compost (DM), yard waste compost (YW), or blood meal soil amendments and sprayed with aerated (ACT) or nonaerated (NCT) compost tea. Mean and standard error of 6 replicate plots with 4 plants per plot. Ripe fruit were harvested weekly and all ripe and nonripe fruit were harvested at the end of the season.

Early blight was the only foliar disease observed in experiment 1 with leaf lesions first appearing the third week of July. Disease severity varied significantly $(\mathrm{P}=0.0068)$ among compost treatments in experiment 1 and was positively correlated $(r=0.3)$ with dry shoot biomass at the end of the season. Plants treated with Premium ${ }^{\circledR}$ composted dairy manure had significantly higher $(\mathrm{P}<0.05)$ disease severity than plants treated with the composted hardwood bark/blood meal combination. However, CT had no significant effect on plant disease level (Figure 3.7). 
In experiment 2, early blight leaf lesions were first observed in the second week of July but disease severity was low. Leaf lesions of Septoria leaf spot were observed the second week of August and increased rapidly, dominating disease ratings by the end of the season. The main effect of CT treatments on disease severity was significant $(\mathrm{P}=0.0493)$. Plants treated with aerated dairy $\mathrm{CT}$ had significantly lower $(\mathrm{P}<0.05)$ disease severity $($ mean=193) than plants treated with nonaerated yard waste CT (mean=346) although neither differed significantly from the tap water control (Figure 3.8).

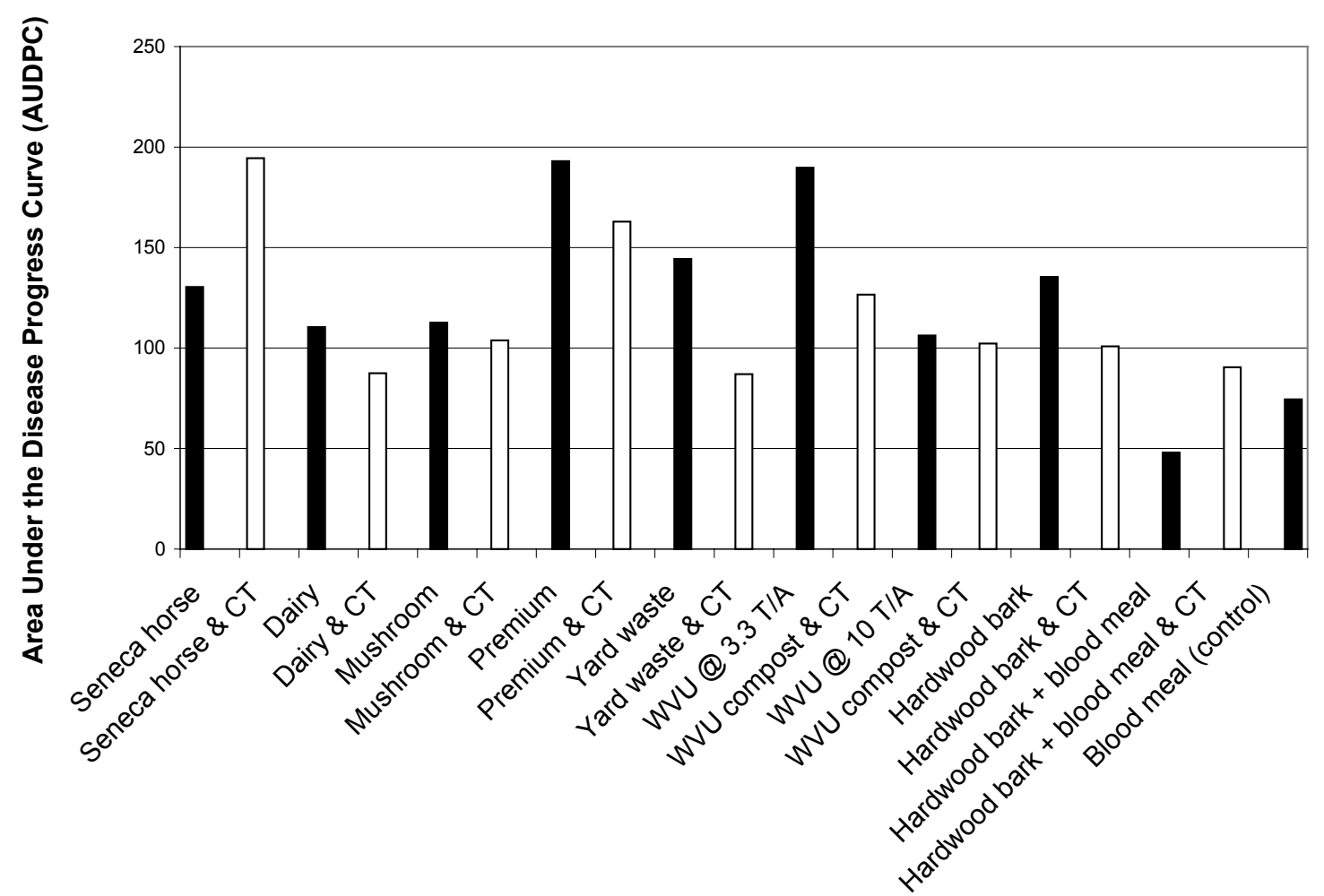

Figure 3.7. Experiment 1: early blight severity in compost and compost tea treatments expressed


season the products of the number of days between disease severity ratings times the rating on that date. 




Figure 3.8. Experiment 2: foliar disease severity in compost and compost tea treatments

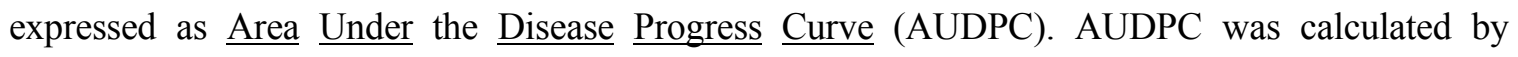
summing over the season the products of the number of days between disease severity ratings times the rating on that date and includes combined severity of early blight and Septoria leaf spot. 


\section{Discussion}

Irrigation was used in experiment 1 (2002) but not in experiment 2 (2004). Despite irrigation, overall conditions in experiment 1 were probably too dry for a major disease epidemic. Temperatures in 2002 were above average from June through September $\left[70.2^{\circ} \mathrm{F}\right.$. $\left(\right.$ mean $\left.=69.4^{\circ}\right)$, $75.1^{\circ}\left(73.5^{\circ}\right), 73.2^{\circ}\left(72.1^{\circ}\right)$, and $68.0^{\circ}\left(65.9^{\circ}\right)$, respectively], and rainfall was below average from July through September [3.14 (4.04), 2.60 (3.96), and 2.73 (3.35) inches, respectively]. Wetter conditions would have favored the pathogen, increased disease pressure, and permitted a more powerful test of the hypothesis. Moderate defoliation resulted from tomato hornworms, but this insect pressure did not appear to alter the overall results with respect to plant growth, fruit yield, or disease incidence. Moreover, tomato plants are herbivory-tolerant and can compensate for substantial foliar damage with additional growth (Thaler, 1999).

Temperatures in 2004 were below average in June, July, and August [68.6 $\left(\right.$ mean $\left.=69.4^{\circ}\right), 72.4^{\circ}$ $\left(73.5^{\circ}\right), 69.7^{\circ}\left(72.1^{\circ}\right)$ F., respectively] and above average in September $\left[66.7^{\circ}\left(65.9^{\circ}\right)\right.$ F. Rainfall was below average in July [3.58 (4.24)] and above average in June, August and September [4.26 (4.04), 5.5 (3.96), and 4.83 (3.35) inches, respectively]. Cooler, wetter conditions contributed to greater disease pressure in experiment 2. Plant biomass was greater but fruit production lower in 2004 compared to 2002. Early blight symptoms first appeared in mid-July in 2004, but relatively dry conditions that month kept disease at low levels despite repeated spray inoculation with a spore suspension of the pathogen. The first Septoria leaf spot symptoms appeared in mid-August, but disease development was more rapid than early blight. Disease severity was not rated separately because symptoms of the two diseases could not be consistently distinguished, particularly after foliage senescence. Percent necrotic tissue estimated for the last 5 weeks was the sum of foliar disease severity for both diseases. Septoria leaf spot accounted for most of the total foliar necrosis by the end of experiment 2 .

The main treatment effects of experiments 1 and 2 are summarized in Table 3.4. Experiment 1 tested composts from 5 feedstocks: dairy manure, horse manure, spent mushroom, hardwood bark, and yard waste. Composted hardwood bark was combined with blood meal in one of the treatments. WVU composted dairy manure was applied at 10 tons/acre in one treatment, but all other compost treatments were at the low rate of 3.3 tons/acre. This wide range of soil amendments resulted in significant differences among treatments. In experiment 2, all compost treatments were 10 
tons/acre, a more typical rate for organic crop production, and the blood meal rate was 2.5 times the rate of experiment 1 . The higher fertility supplied by soil treatments in experiment 2 probably explains some of the differences in results, when compared with experiment 1

Table 3.4. Main effects of compost amendments and extracts

\begin{tabular}{|l|l|l|l|}
\hline Treatment & Parameter & $\mathbf{2 0 0 2}$ & $\mathbf{2 0 0 4}$ \\
\hline & Biomass & $*$ & $*$ \\
Soil Treatment & Fruit Weight & $*$ & $*$ \\
Fruit Number & $*$ & $*$ \\
& Disease & $*$ & -- \\
GLAR & $* *$ & $*$ \\
\hline CT Treatment & Biomass & -- & -- \\
& Fruit Weight & -- & -- \\
& Fruit Number & -- & -- \\
& Disease & - & $*$ \\
\hline
\end{tabular}

* indicates statistical significance $(\mathrm{P}<0.05)$

** indicates marginal significance $(\mathrm{P}<0.10)$

\section{Effects of Soil Treatments on Yield and Disease}

Plant growth and fruit yield differed significantly $(\mathrm{P}=0.001)$ among soil treatments in both experiments. In experiment 1 , highest plant growth and greatest fruit yield occurred with yard waste and WVU dairy manure composts and lowest yields with hardwood bark compost, blood meal, and the combined blood meal/hardwood bark compost treatment. Blood meal was combined with composted hardwood bark in order to increase the soil nitrogen supply. Surprisingly, this 
combination resulted in lower plant growth and fruit yield than composted hardwood bark or blood meal alone. Among the dairy manure compost treatments at 3.3 tons/acre, the two commercially produced composts resulted in less growth than WVU dairy manure compost, suggesting that compost from similar feedstocks may differ significantly in growth promotion.

Experiment 1 served as the initial compost screen. Experiment 2 narrowed soil treatments to yard waste compost, WVU dairy manure compost, and blood meal as the control with 30 replicates of each treatment. In experiment 2, blood meal resulted in greater plant growth and fruit yield than compost amendments, and the increase was significant $(\mathrm{P}<0.05)$ compared to yard waste compost. Lower plant growth and fruit yield with blood meal in experiment 1 and higher growth and yield with blood meal in experiment 2 suggest that the nitrogen supplied by blood meal was not balanced with the amount of nitrogen supplied by the compost in either experiment. This contrasts with field trials by Abbasi et al. (2002) which evaluated the effects of soil amendments derived from composted yard and cannery wastes on tomato production over two growing seasons. Foliar analyses confirmed that $\mathrm{N}, \mathrm{P}$, and $\mathrm{K}$ levels at a low compost loading rate were equivalent to levels supplied by chemical fertilizer in the control plots. It is unlikely that nutrient differences had an effect on observed results in that study, but probable that they did in these experiments, as was also evident in the compost rate trial (Chapter 1).

The wide range of soil treatments in experiment 1 had a significant effect $(\mathrm{P}=0.0068)$ on plant disease severity; the narrower range of treatments in experiment 2 did not. This was primarily a function of the hardwood bark treatment in experiment 1 , which resulted in plants that were visibly more stunted than all other plants in either experiment. In experiment 1, plants treated with Premium ${ }^{\circledR}$ composted dairy manure had significantly higher disease severity $(\mathrm{P}<0.05)$ than plants treated with composted hardwood bark/blood meal. Neither WVU dairy manure compost treatment (at the 3.3 or 10 tons/acre rate) differed significantly in terms of disease severity from yard waste compost or from the control. The same was true in experiment 2: yard waste compost and WVU dairy manure did not differ from each other or from the control. Abbasi et al. (2002) had similarly inconsistent results with compost soil amendments for disease control. Bacterial spot incidence on fruit was reduced in one of two years of conventional field trials, and a high compost rate treatment reduced anthracnose on fruit in one of two years in organic field trials. However, compost amendments increased foliar disease (bacterial spot and Septoria leaf spot) in both years of the conventional field trials. By contrast, another recent study reports limited success in the compost- 
mediated control of bacterial speck: compost soil amendments appeared to induce plant resistance to the pathogen in tomato and Arabidopsis thaliana plants in growth chamber experiments. Disease symptoms were reduced $35 \%$ to $65 \%$ on plants in composted paper mill-amended soils relative to plants in non-amended control plots or soil amended with non-composted paper mill residuals (Vallad et al., 2003).

\section{Effects of CT on Disease Severity}

CT had a significant effect on disease severity in experiment $2(\mathrm{P}=0.0493)$ but not in experiment 1 . Plants treated with nonaerated yard waste CT in experiment 2 had higher disease severity $(\mathrm{P}<0.05)$ than plants treated with aerated dairy manure CT. However, neither treatment differed significantly from the control. Orthogonal contrast analysis indicates that the difference in effect on disease severity was due to compost feedstock rather than the factor of aeration. Plants treated with dairy manure CT (aerated or nonaerated) had significantly lower disease severity $(\mathrm{P}=0.0149)$ than plants treated with yard waste CT (aerated or nonaerated).

Few replicated studies on CT in tomato production are available, but research attention has been given to non-compost tea foliar sprays of a number of biotic and abiotic compounds known to induce SAR to a variety of pathogens. The plant activator acibenzolar-S-methyl (Actigard, Syngenta Crop Protection, Greensboro, NC) applied as a foliar spray has been tested in several field studies as an SAR inducer for the management of tomato pathogens. Louws et al. (2001) found Actigard as effective as a standard copper bactericide spray program in controlling bacterial speck and bacterial spot. Actigard reduced total foliar disease and decreased the incidence of anthracnose on fruit compared to a control over two years in the conventional field study by Abbasi et al. (2002). Actigard application to tomato plants induced several known pathogenesis-related (PR) proteins and reduced the incidence of bacterial spot, early blight, and leaf mold relative to a control in a field study (Inbar et al., 1998).

Another SAR inducer, $\beta$-aminobutyric acid, was tested in a greenhouse study. Induction of resistance by this compound reduced late blight disease severity in tomato plants challenged with Phytophthora infestans. Accumulation of PR proteins was positively correlated with protection against late blight, yet the actual mechanism of disease control in that study was not apparent (Cohen et al., 1994). 


\section{Main Effects and Interactions}

In experiment $1, \mathrm{CT}$ had no significant effects on plant growth or fruit yield. In experiment 2, the interaction of $\mathrm{CT}$ with soil amendment on total fruit number was marginally significant $(\mathrm{P}=0.0848)$. Plants receiving blood meal produced a greater number of fruit $(\mathrm{P}<0.05)$ than plants receiving yard waste or dairy manure compost. Among the 5 main CT treatments, the greatest difference was between high fruit number associated with dairy manure aerated compost tea (DM-ACT) and low fruit number associated with dairy manure nonaerated compost tea (DM-NCT). The interaction between compost amendments and CT can be seen in the simple effects. The number of fruit in plots with blood meal/DM-ACT was greater than in plots with blood meal/DM-NCT. The same trend occurred with these teas in yard waste compost plots, but the reverse trend occurred with dairy manure compost plots.

The data in Table 3.5 standardize yield in experiments 1 and 2 by production per plant and disease severity by treatment. The data represent treatments repeated in the two experiments: WVU composted dairy manure at 10 tons/acre with and without nonaerated compost tea.

Table 3.5. Effects of compost amendments and extracts on yield and disease in experiments

1 and 2

\begin{tabular}{|l|l|l|l|l|}
\hline $\begin{array}{l}\text { Experiment } \\
\text { and treatment }\end{array}$ & $\begin{array}{l}\text { Dry shoot } \\
\text { biomass } \\
\text { (g/plant) }\end{array}$ & $\begin{array}{l}\text { Fruit } \\
\text { (kg/plant) }\end{array}$ & $\begin{array}{l}\text { Fruit to biomass } \\
\text { ratio }\end{array}$ & $\begin{array}{l}\text { Area under the } \\
\text { disease progress } \\
\text { curve }\end{array}$ \\
\hline 2002 Compost & 126 & 4.3 & 34.1 & 106 \\
\hline Compost \& tea & 107 & 4.2 & 39.3 & 102 \\
\hline & & & & 207 \\
\hline 2004 Compost & 185 & 3.0 & 16.2 & 170 \\
\hline Compost \& tea & 152 & 3.5 & 23.0 & \\
\hline
\end{tabular}


In experiment 1 , the blood meal control treatment of $60 \mathrm{lbs}$. $\mathrm{N}$ per acre was considerably below a more typical application of 100 to $150 \mathrm{lbs}$. N per acre needed to meet the high nitrogen demand of tomatoes. Due to these low nutrient rates, plants in several treatments were visibly stunted, though all of them yielded fruit. Large plants form a closed canopy, trapping moisture and creating a favorable microclimate for the pathogen. Smaller plants lacking such a canopy are subject to less disease pressure. The results appear to support this: compost treatments with the greatest plant growth also had the highest disease severity. Conversely, treatments with the lowest plant growth had the lowest rate of disease. Plant spacing was closer than normally recommended in order to promote disease development in the experiment. A closed canopy would favor the pathogen and increase the chance of a disease epidemic in a wet season by increasing leaf wetness periods and decreasing ultraviolet radiation (Rotem, 1994). Increasing the distance between plants might reduce disease levels, though at some cost to productivity.

In experiment 2, the blood meal control treatment of $150 \mathrm{lbs} . \mathrm{N}$ per acre produced more plant growth and fruit than either compost amendment. However, percent GLAR for plants treated with blood meal was significantly lower at the end of the season than percent GLAR for plants treated with either compost, and the reduction compared to dairy manure compost was significant $(\mathrm{P}<0.05)$. Blood meal apparently supplied more readily available nitrogen for vigorous plant growth and fruit production than did the compost amendments. This was evident from visibly darker green foliage of plants in the blood meal plots and was confirmed by analysis of total nitrogen in leaf samples taken from plants (Appendix, Table 3.6).

Lower fertility apparently resulted in lower fruit yield and shoot biomass in plots amended with compost, but higher percent GLAR at the end of the 2004 season suggests that the nutrient release from compost was more prolonged. This is consistent with the literature indicating that compost functions as a slow-release fertilizer (Rodale, 1973). Plants in blood meal plots grew faster and larger and produced more fruit, but also died back more quickly as available soil nitrogen was depleted. Compost applied at a rate higher than 10 tons/acre might have supplied sufficient nitrogen for plants to achieve biomass and fruit yield comparable to the plants in the blood meal plots.

Shoot biomass at the end of the growing season in experiment 1 was positively correlated $(\mathrm{P}=0.01)$ with early blight severity. Larger plants generally had higher disease severity than smaller plants. This indicates that early blight disease pressure did not limit plant growth in this experiment. 
However, the single GLAR rating at the end of the season was also positively correlated with disease severity. Smaller plants had less disease but also lower percent GLAR than larger plants. Disease pressure thus does not appear to explain the faster senescence of smaller plants in experiment 1. Low plant vigor associated with low soil fertility might better explain rapid senescence than does disease pressure.

In experiment 2, shoot biomass was negatively correlated with disease severity. Smaller plants generally had higher disease severity than larger plants. This negative correlation suggests that foliar disease (early blight and Septoria leaf spot) limited plant growth. However, fruit yield was positively correlated with disease severity in both 2002 and 2004, indicating that disease did not limit fruit production in either experiment.

Weekly percent GLAR ratings in experiment 2 were essentially the inverse of disease severity ratings: high percent GLAR correlated negatively with disease severity. This negative correlation suggests that compost soil amendments might have an effect on foliar disease severity if compost amendment rate were an additional explanatory variable. The 10 tons/acre rate may have been below a critical threshold for effective disease control, but only a single application rate was tested in this experiment. By contrast, Abbasi et al. (2002) applied soil amendments derived from composted yard waste and composted cannery waste at variable rates up to 30 tons/acre in organic field trials and at up to 74 tons/acre in conventional field trials. Effects on disease severity were inconsistent over two years of field trials. The high compost rate in the organic system resulted in reduction of anthracnose on ripe fruit in one year, but compost amendments at low and high rates increased foliar diseases (bacterial spot and Septoria leaf spot) both years.

The data indicate that $\mathrm{CT}$ had no significant interaction with compost amendments on disease severity. Unless compost amendments have a systemic effect at the rhizosphere level, CT effects on the foliar diseases in question appear to be mainly a function of phyllosphere biology. 
The yield and disease data in Table 3.7 summarize the effects of WVU composted dairy manure applied at 10 tons/acre in experiments 1 and 2 and in the compost rate experiment (Chapter 1) on plant growth, fruit yield, and disease severity.

Table 3.7. Effect of compost soil amendments on yield and disease in three experiments

\begin{tabular}{|l|lr|l|l|l|l|}
\hline Experiment & $\begin{array}{l}\text { Dry shoot } \\
\text { biomass } \\
\text { plant) }\end{array}$ & $\begin{array}{l}\text { Fresh fruit (kg/ } \\
\text { plant) }\end{array}$ & $\begin{array}{l}\text { Fruit weight } \\
\text { to } \begin{array}{l}\text { Area under } \\
\text { biomass } \\
\text { ratio }\end{array}\end{array}$ & $\begin{array}{r}\text { disease } \\
\text { progress curve }\end{array}$ \\
\hline Compost Rate & 239 & 4.6 & 19.2 & 203 \\
\hline Experiment 1 & 126 & 4.3 & 34.1 & 104 \\
\hline Experiment 2 & 185 & 3.0 & 16.2 & 207 \\
\hline
\end{tabular}

Compost amendments have been applied to the compost rate trial plots at 10 tons/acre for 4 consecutive years. In experiments 1 and 2, compost was applied at 10 tons/acre only in the year of each experiment. The higher shoot biomass and fruit yield in the compost rate plots suggest a cumulative fertility effect when compost amendments are applied over consecutive years. Plant response may also reflect other soil differences at the two sites. A surprising result was higher fruit production per plant in experiment 1 than experiment 2 despite lower shoot biomass. Experiment 1 plants produced more than twice as much fruit per gram shoot biomass as plants in experiment 2 . This may be explained in part by plant resource partitioning resulting from differences in weather conditions. The smaller plants in the warmer, drier growing season of 2002 compensated for less vegetative growth with more fruit production. The cooler, wetter conditions of 2004 resulted in vegetative growth at the expense of fruit production. 
In neither experiment did CT significantly reduce disease severity compared to the control. In both experiments soil amendments had greater and more consistent effects on plant growth and fruit yield than did CT treatments applied to foliage. However, NCT from yard waste compost in experiment 1 had a significant interaction with yard waste compost in reducing shoot biomass. In experiment 2, NCT from dairy manure compost had a marginally significant interaction with soil amendments in reducing total fruit number. Interaction between soil amendments and compost tea was minimal in both experiments and pertained only to yield. For growers, biomass and fruit reduction resulting from CT application are clearly undesirable outcomes. The degree of interaction between compost amendments and extracts on disease and yield, while minimal in these experiments, is probably specific by crop and by host/pathogen relationship. 


\section{CONCLUSIONS}

CT made from hay compost reduced disease severity compared to a control while CT from a mushroom compost increased disease severity in greenhouse plants.

Cultivar was a significant factor in one greenhouse experiment: the heirloom 'Brandywine' had significantly greater disease severity than ' $\mathrm{WV}$ '63.'

Dairy manure compost amendments applied at 10 and 20 tons/acre reduced disease severity of early blight compared to rates of 2.5 and 5 tons/acre.

Composts, made from similar materials and applied as soil amendments, differed in their effects on plant growth and disease severity.

In one field experiment, disease severity of early blight and Septoria leaf spot was significantly lower for plants treated with ACT from dairy manure than plants treated with yard waste NCT, but neither CT differed significantly from a tap water control.

Nonaerated dairy manure CT had a marginally significant interaction with compost amendments in reducing total fruit number.

Disease severity was positively correlated with fruit production: early blight did not appear to limit yield in any of three field experiments. 


\section{APPENDIX}

Table 2.1. Compost nutrient analysis

\begin{tabular}{|l|l|l|l|l|l|l|l|l|}
\hline Compost & C:N Ratio & $\mathbf{N}$ & $\mathbf{P}$ & $\mathbf{K}$ & $\mathbf{N H}_{3}$ & $\mathbf{C u}$ & $\mathbf{C a}$ & $\mathbf{M g}$ \\
\hline & & & & & & & & \\
\hline Dairy & 18.66 & 0.48 & 0.56 & 0.32 & 0.04 & 0.0002 & 1.02 & 0.10 \\
\hline Hay & 26.05 & 1.24 & 0.41 & 0.45 & 0.11 & 0.0007 & 0.65 & 0.16 \\
\hline Horse & 42.95 & 0.42 & 0.41 & 0.16 & 0.18 & 0.0012 & 0.24 & 0.12 \\
\hline Mushroom & 23.73 & 0.54 & 0.67 & 0.46 & 0.17 & 0.0094 & 1.03 & 0.14 \\
\hline Poultry & 27.58 & 0.92 & 1.52 & 0.31 & 0.11 & 0.0006 & 3.02 & 0.17 \\
\hline Vermiculture & 28.95 & 0.70 & 0.77 & 1.37 & 0.06 & 0.0025 & 0.90 & 0.29 \\
\hline Yard waste & 32.32 & 0.56 & 0.39 & 0.18 & 0.09 & 0.0001 & 1.23 & 0.07 \\
\hline
\end{tabular}

Nutrient analysis of macronutrient, micronutrients, and carbon:nitrogen ratio of composts was done by the West Virginia Department of Agriculture Nutrient Management Lab in Moorefield, WV. All nutrient values are reported as percentages of fresh material. 
Table 3.6. Tomato leaf tissue analysis

\begin{tabular}{|l|l|l|l|}
\hline Treatment & \%Carbon & \%Sulfur & \%Nitrogen \\
\hline & & & \\
\hline Dairy \& D+ & 40.03 & 0.6992 & 3.806 \\
\hline Dairy \& D- & 41.01 & 0.5692 & 4.035 \\
\hline Dairy \& Y+ & 40.69 & 0.7222 & 3.830 \\
\hline Dairy \& Y- & 40.93 & 0.7841 & 3.858 \\
\hline Dairy \& tap water & 41.03 & 0.6233 & 3.891 \\
\hline Yard waste \& D+ & 41.58 & 0.6799 & 3.924 \\
\hline Yard waste \& D- & 41.69 & 0.6797 & 4.017 \\
\hline Yard waste \& Y+ & 40.65 & 0.7321 & 3.703 \\
\hline Yard waste \& Y- & 40.92 & 0.6937 & 3.700 \\
\hline Yard waste \& tap water & 41.07 & 0.6571 & 3.954 \\
\hline Blood meal \& D+ & 42.22 & 0.3956 & 4.876 \\
\hline Blood meal \& D- & 42.72 & 0.3773 & 4.766 \\
\hline Blood meal \& Y+ & 42.26 & 0.3643 & 4.811 \\
\hline Blood meal \& Y- & 42.06 & 0.3837 & 4.645 \\
\hline Blood meal \& tap water & 42.63 & 0.3504 & 5.047 \\
\hline
\end{tabular}

Total percentage of carbon, sulfur, and nitrogen in leaf samples from tomato plants in 2004 field experiment. Eight leaves from each plot were harvested, aggregated by treatment, and analyzed with a $L E C O C S N-2000$. 


\section{LITERATURE CITED}

Abbasi, P., Al-Dahmani, J., Sahin, F., Hoitink, H., and Miller, S. 2002. Effect of compost amendments on disease severity and yield of tomato in conventional and organic production systems. Plant Disease 86:156-61.

Barclay, G., Murphy, H., Manzer, F., and Hutchinson, F. 1973. Effects of differential rates of nitrogen and phosphorus on early blight in potatoes. American Potato Journal 50:42-48.

Boehm, M., Madden, L., and Hoitink, H. 1993. Effect of organic matter decomposition level on bacterial species diversity and composition in relationship to Pythium damping-off severity. Applied and Environmental Microbiology 59:4171-4179.

Boulter, J., Boland, G., and Trevors, J. 2002. Evaluation of composts for suppression of dollar spot (Sclerotinia homoeocarpa) of turfgrass. Plant Disease 86:405-410.

Brinton, W., Tränkner, A., and Droffner, M. 1996. Investigations into liquid compost extracts. BioCycle 37:68-70.

Bulluck, L. and Ristaino, J. 2002. Effect of synthetic and organic soil fertility amendments on southern blight, soil microbial communities, and yield of processing tomatoes. Phytopathology 92:181-189.

Chalker-Scott, L. 2001. The myth of compost tea. Washington State Nursery and Landscape Association Bulletin 53:4.

Chen, W., Hoitink, H., and Schmitthenner, A. 1987. Factors affecting suppression of Pythium damping-off in container media amended with composts. Phytopathology 77:755-760. 
Cohen, Y., Niderman, T., Moesinger, E., and Fluhr, R. 1994. $\beta$-aminobutyric acid induces the accumulation of pathogenesis-related proteins in tomato (Lycopersicon esculentum L.) plants and resistance to late blight infection caused by Phytophthora infestans. Plant Physiology 104:59-66.

Craft, C. and Nelson, E. 1996. Microbial properties of composts that suppress damping-off and root rot of creeping bentgrass caused by Pythium graminicola. Applied and Environmental Microbiology 62:1550-57.

Cronin, M., Yohalem, D., Harris, R., and Andrews, J. 1996. Putative mechanism and dynamics of inhibition of the apple scab pathogen Venturia inaequalis by compost extracts. Soil Biology and Biochemistry 28:1241-1248.

De Brito Alvarez, M., Gagne, S., and Antoun, H. 1995. Effect of compost on rhizosphere microflora of the tomato and on the incidence of plant growth-promoting rhizobacteria. Applied and Environmental Microbiology 61:194-199.

De Meyer, G. and Hoefte, M. 1997. Salicylic acid produced by the rhizobacterium Pseudomonas aeruginosa 7NSK2 induces resistance to leaf infection by Botrytis cinerea on bean. Phytopathology 87:588-93.

Diver, S. 1998. Compost Teas for Plant Disease Control. 1998. ATTRA publication, Fayetteville, AS.

Diver, S., Kuepper, G., and Born, H. 1999. Organic tomato production: horticulture production guide. www.attra.org/attra-pub/tomato.html

Fravel, D. 1988. Role of antibiosis in the biocontrol of plant diseases. Annual Review of Phytopathology 26:75-91.

Fukoka, M. 1978. The One Straw Revolution. Rodale Press, Emmaus, PA. 
Gliessman, S. 1998. Agroecology: Ecological Processes in Sustainable Agriculture. Ann Arbor Press, Chelsea, MI.

Goldstein, A. 1986. Bacterial solubilization of mineral phosphates: historical perspective and future prospects. American Journal of Alternative Agriculture 1:51-57.

Granatstein, D. 1999. Foliar disease control using compost tea. The Compost Connection for Western Agriculture 8:1-4.

Harman, G. 2000. Myths and dogmas of biocontrol: changes in perceptions from research on Trichoderma harzianum T-22. Plant Disease 84:377-393.

Hoitink, H., Stone, A., and Han, D.1997. Suppression of plant diseases by compost. Hortscience 32:184-187.

Hoitink, H., Vandoren, D., and Schmitthenner, A. 1977. Suppression of Phytophthora cinnamomi in a composted hardwood bark potting medium. Phytopathology 67:561-565.

Hoitink, H. and Fahy, P. 1986. Basis for the control of soilborne plant pathogens with composts. Annual Review of Phytopathology 24:93-114.

Hunt, P., Smart, G., and Eno, C. 1973. Sting nematode, Belonolaimus longicaudatus, immotility induced by extracts of composted municipal refuse. Journal of Nematology 5:60-63.

Ingham, E. 2002. The Compost Tea Brewing Manual. Soil Foodweb, Inc., Corvallis, OR.

Inbar, M., Doostdar, H., Sonoda, R.M., Leibee, G.L., and Mayer, R.T. 1998. Elicitors of plant defensive systems reduce insect densities and disease incidence. Journal of Chemical Ecology 24:135-149.

Jackson, W. 1980. New Roots for Agriculture. Friends of the Earth, San Francisco, CA. 
Jones, J., Stall, R., and Zitter, T. 1997. Compendium of Tomato Diseases. American Phytopathological Society, St. Paul, MN.

Kim, K., Nemec, S., and Musson, G. 1997. Effects of composts and soil amendments on soil microflora and Phytophthora root and crown rot of bell pepper. Crop Protection 16:165-172.

Kuter, G., Hoitink, H., and Chen, W. 1988. Effects of municipal sludge compost curing time on suppression of Pythium and Rhizoctonia diseases of ornamental plants. Plant Disease 72:751-756.

Leong, J. 1986. Siderophores: their biochemistry and possible role in the biocontrol of plant pathogens. Annual Review of Phytopathology 24:187-209.

Louws, F.J., Wilson, M., Campbell, H.L., Cuppels, D.A. Jones, J.B., Shoemaker, P.B., Sahin, F., and Miller, S.A. 2001. Field control of bacterial spot and bacterial speck of tomato using a plant activator. Plant Disease 85:481-488.

MacNab, A. and Beyer, D. 1996. Tomato early blight and yield associated with spent-mushroomcompost and fungicide treatments. Biological and Cultural Tests 11:78.

Maloy, O. and Murray, T. 2001. Encyclopedia of Plant Pathology, Vol. 1. John Wiley \& Sons, Inc., New York, NY.

McGovern, R. and Obreza, T. 1993. Effect of irrigation deficit and processed sludge on early blight of fresh market tomatoes. Biological and Cultural Tests 8:55.

McGrath, M. 1996. Evaluation of yard-waste compost alone or in combination with fungicides for managing Phytophthora crown and fruit rot in pumpkin. Biological and Cultural Tests 25:115.

Moore, W. 1942. Some factors affecting the infection of tomato seedlings by Alternaria solani. Phytopathology 32:399-403. 
Murphy, J.F., Zehnder, G.W., Schuster, D.J., Sikora, E.J., Polston, J.E., and Kloepper, J.W. 2000. Plant growth-promoting rhizobacterial mediated protection in tomato against Tomato mottle virus. Plant Disease 84:779-784.

Nelson, E. and Hoitink, H. 1981. The role of microorganisms in the suppression of Rhizoctonia solani in container media amended with composted hardwood bark. Phytopathology 73:274-278.

Newman, E. 1966. A method of estimating the total length of root in a sample. Journal of Applied Ecology 3:139-145.

Pharand, B., Carisse, O., and Benhamou, N. 2002. Cytological aspects of compost-mediated induced resistance against Fusarium crown and root rot in tomato. Phytopathology 92:424-438.

Ringer, C. 1998. Bibliography on compost for disease suppression. USDA Microbial Lab, Beltsville, MD. http://ncatark.uark.edu/ steved/compost-disease-biblio.html

Rodale, J.I. 1973. The Complete Book of Composting. Rodale Press, Emmaus, PA.

Rotem, J. 1994. The Genus Alternaria: Biology, Epidemiology, and Pathogenicity. APS Press, St. Paul, MN.

Sahin, F. and Miller, S. 1996. Characterization of Ohio strains of Xanthomonas campestris pv. vesicatoria, causal agent of bacterial spot of pepper. Plant Disease 80:773-778.

Scheuerell, S. and Mahaffee, W. 2002. Compost tea: principles and prospects for plant disease control. Compost Science and Utilization 10: 313-338.

Simmons, E. 2000. Alternaria themes and variations (244-286): Species on Solanaceae. Mycotaxon 75:1-115.

Stephens, C., Herr, L., Hoitink, H., and Schmitthenner, A. 1981. Control of Rhizoctonia dampingoff by the use of composted hardwood bark. Plant Disease 65:796-797. 
Thaler, J.S. 1999. Induced resistance in agricultural crops: effects of jasmonic acid on herbivory and yield in tomato plants. Environmental Entomology 28:30-37.

http://www.ams.usda.gov/nop/indexIE.htm

Vallad, G.E., Cooperband, L.R., and Goodman, R.M. 2003. Plant foliar disease suppression mediated by composted forms of paper-mill residuals exhibits molecular features of induced resistance. Physiological and Molecular Plant Pathology 63:65-77.

Vallad, G.E. and Goodman, R.M. 2004. Systemic acquired resistance and induced systemic resistance in conventional agriculture. Crop Science 44:1920-1934.

Van Bruggen, A. and Semenov, A. 2000. In search of biological indicators for soil health and disease suppression. Applied Soil Ecology 15:13-24.

Voland, R. and Epstein, A. 1994. Development of suppressiveness to diseases caused by Rhizoctonia solani in soils amended with composted and noncomposted manure. Plant Disease 78:461-466.

Waggoner, P.E. and Horsfall, J.S. 1969. EPIDEM-A simulator of plant disease written for a computer. Connecticut Agricultural Experiment Station Bulletin 698.

Wei, G., Kloepper, J., and Tuzun, S. 1996. Induced systemic resistance to cucumber diseases and increased plant growth by plant growth-promoting rhizobacteria under field conditions. Phytopathology 86:221-224.

Weltzien, H. and Ketterer, N. 1986. Control of powdery mildew, Plasmopara viticola (de Bary) Berlese et de Toni, on grapevine leaves through water extracts from composted organic wastes. Journal of Phytopathology 116:186-188.

Weltzien, H. 1991. Biocontrol of foliar fungal diseases with compost extracts. In: Microbial Ecology of Leaves. Andrews, J. and Hirano, S. (eds.). Springer-Verlag, NY. 
Wright, E., Rivera, M., Cheheid, A., Fabrizio, M., and Mosedale, J. 1999. Promotion of growth and control of damping-off (Rhizoctonia solani) of greenhouse tomatoes amended with vermicompost. Biological and Cultural Tests 14:177.

Yohalem, D., Voland, R., Nordheim, E., Harris R., and Andrews, J. 1996. Sample size requirements to evaluate spore germination inhibition by compost extracts. Soil Biology and Biochemistry 28:519-525.

Zhang, W., Han, D., Dick, W., Davis, K., and Hoitink, H. 1998. Compost and compost water extract-induced systemic acquired resistance in cucumber and Arabidopsis. Phytopathology $88: 450-455$.

Zehnder, G.W., Murphy, J.F., Sikora, E.J., and Kloepper, J.W. 2001. Application of rhizobacteria for induced resistance. European Journal of Plant Pathology 107:39-50.

Zitter, T. and Wolfe, D. 1989. Effects of nitrogen rates, foliar area, fungicide application and varietal susceptibility on early blight and tomato yield. Biological and Cultural Tests 4:30. 